JURNAL KETAHANAN NASIONAL

Vol. 26, No. 2, Agustus 2020, Hal 204-228

DOI:http://dx.doi.org/ 10.22146/jkn.47285

ISSN:0853-9340(Print), ISSN:2527-9688(Online)

Online sejak 28 Desember 2015 di :http://jurnal.ugm.ac.id/JKN

VOLUME 26

No. 2, Agustus 2020

Halaman 204-228

\title{
Pembangunan Ekonomi Pertanian Digital Dalam Mendukung Ketahanan Pangan \\ (Studi di Kabupaten Sleman: Dinas Pertanian, Pangan, dan Perikanan, Daerah Istimewa Yogyakarta)
}

\author{
Eko Tulus Wibowo \\ Institut Pertanian Stiper, D. I. Yogyakarta \\ email:wibowoe36@gmail.com
}

Dikirim:25-06-2020; Direvisi: 10-08-2020; Diterima:28-08-2020

\begin{abstract}
Food was basic need for human life coming from the agricultural sector. The role of agriculture began to declined development priorities shift to non-agricultural sector. One innovation in agriculture was the use of technology in the form of a digital agricultural platform for economic purposes. This study aimed to determined the importance of digital agricultural economic development developed by the Department of Agriculture, Food and Fisheries in supporting food resilience in Sleman Regency, Yogyakarta Special Region Province

This article was the result of a descriptive study with a qualitative approach. Data collection techniques used were observation, interviews, focus group discussions, documentation and literature, and documents from the internet. Furthermore, data analysis used was data categorization, data reduction, data presentation, and drawing conclusions. Meanwhile, the study was conducted in Sleman Regency.

This article stated that the economy of digital agriculture provided benefits in the agricultural process. In this article the problems, benefits, and strategies in developing a digital agricultural economy and digital agricultural economy were built up from a program developed by Department of Agriculture, Food and Fisheries. In addition, the economy of digital agriculture was capable to supported food resilience in Sleman Regency as seen from the benefits received by users through three aspects, namely availability, access, and consumption.
\end{abstract}

Keywords: Digital Agricultural Economy; Food Resilience; Sleman Regency.

\begin{abstract}
ABSTRAK
Pangan merupakan kebutuhan yang mendasar bagi kehidupan manusia yang berasal dari sektor pertanian. Peran pertanian mulai menurun searah dengan prioritas pembangunan beralih ke sektor non pertanian. Salah satu inovasi bidang pertanian adalah pemanfaatan teknologi berupa ekonomi pertanian digital. Penelitian ini bertujuan untuk mengetahui pentingnya pembangunan ekonomi pertanian digital yang dikembangkan oleh Dinas Pertanian, Pangan, dan Perikanan dalam mendukung ketahanan pangan di Kabupaten Sleman, Daerah Istimewa Yogyakarta.

Artikel ini merupakan hasil dari penelitian deskriptif dengan pendekatan kualitatif. Teknik pengumpulan data yang digunakan adalah observasi, wawancara, focus group discussion, dokumentasi dan kepustakaan, serta dokumen dari internet. Selanjutnya, analisis data yang digunakan adalah kategorisasi data, reduksi data, penyajian data, serta penarikan kesimpulan. Sedangkan, lokasi penelitian dilakukan di Kabupaten Sleman.

Artikel ini menyatakan bahwa ekonomi pertanian digital dapat memberikan keuntungan dalam proses pertanian. Dalam artikel ini dijelaskan permasalahan, manfaat, dan strategi dalam membangun ekonomi pertanian digital serta ekonomi pertanian digital yang terbangun dari program yang dikembangkan Dinas Pertanian, Pangan,
\end{abstract}


dan Perikanan Kabupaten Sleman. Selain itu, ekonomi pertanian digital dapat mendukung ketahanan pangan di Kabupaten Sleman dilihat dari manfaat yang diterima oleh pengguna melaui dari tiga aspek yaitu aspek ketersediaan, akses, dan konsumsi.

Kata Kunci: Ekonomi Pertanian Digital; Ketahanan Pangan; Kabupaten Sleman.

\section{PENGANTAR}

Seiring dengan menguatnya pembangunan industri dan jasa, peran pertanian mulai menurun searah dengan prioritas pembangunan yang beralih ke sektor non pertanian. Hal ini menjadikan sektor pertanian dianggap kurang strategis. Masalah yang muncul terkait produk pertanian cukup sulit untuk diatasi. Prioritas untuk pembelanjaan produk pertanian semakin menurun, ini akibat dari sifat produk pertanian yang memiliki elastisitas rendah. Dengan demikian banyak produk pertanian yang tidak terjual secara baik, serta kenaikan nilai jual yang menjadi rendah. Akibatnya penerimaan petani mejadi rendah dan akhirnya pendapatan petani secara umum juga semakin rendah. Kondisi Indonesia yang berupa negara kepulauan menyebabkan tidak berlakunya hukum supply and demand. Distribusi dan logistik mengambil margin yang cukup besar. Pada saat tertentu, produksi pertanian memerlukan waktu lama untuk distribusi. Begitu juga dengan produksi untuk memenuhi kebutuhan di tempat lain. Produksi pertanian selalu ada namun kerap dipertanyakan keberadaannya karena harga yang tinggi. Padahal, produksi tersebut benar ada hanya saja, di beberapa titik tertentu menjadi kurang diminati karena harga merupakan indikator penting dalam mengambil keputusan.

Di sisi yang lain, fakta menunjukkan sektor pertanian telah menjadi penggerak ekonomi bangsa pada berbagai negara. Subejo (2007) mencatat pembangunan pertanian memiliki arti yang sangat strategis, tidak hanya bagi negara-negara berkembang, bagi negara maju pun pertanian tetap mendapat perhatian dan perlindungan yang sangat serius. Membahas pertanian adalah membahas tentang kelangsungan hidup, pertanian adalah penyedia bahan pangan, bahan sandang dan bahkan bahan papan. Selama manusia di dunia masih memerlukan bahan pangan untuk menjamin kelangsungan hidupnya maka pertanian tetap memegang peran yang sangat penting.

Peran teknologi informasi dan komunikasi sangat strategis menyelesaikan berbagai persoalan pertanian misalnya persoalan pertanian di distribusi produk pertanian. Hal yang nyata dialami oleh petani yang berpengaruh terhadap kesejahteraan jika tata niaga perdagangan atau jalur distribusi barang bisa dipangkas. Ini dapat dilihat dari hasil produk pertanian sebelum sampai ke tangan konsumen. Produk pertanian selalu melalui perantara atau pedagang pengumpul. Dari pengepul masuk ke pasar induk lalu didistribusikan ke pengecer di pasar-pasar tradisional. Hal ini membuat jalur distribusi menjadi panjang.

Teknologi informasi dan komunikasi strategis untuk problematika pertanian seiring dengan perkembangan terkini berupa aplikasi teknologi informasi dan komunikasi yang efektif dan efisien. Banyak ahli sepakat bahwa dunia berada di ambang revolusi industri. Perlu dicatat bahwa teknologi informasi memainkan peran penting dalam semua bidang aktivitas manusia. Dalam lingkungan ilmiah ekonomi, fenomena ini 
Eko Tulus Wibowo -- Pembangunan Ekonomi Pertanian Digital Dalam Mendukung Ketahanan Pangan (Studi di Kabupaten Sleman: Dinas Pertanian, Pangan, dan Perikanan, Daerah Istimewa Yogyakarta)

disebut ekonomi digital. Meskipun demikian, isi konsep ini masih belum sepenuhnya jelas. Istilah ekonomi digital sering diganti dengan definisi seperti API economy, ekonomi aplikasi, ekonomi kreatif, Industri 4.0, dll. Namun, konsep ekonomi digital digunakan dalam semua dokumen peraturan (Buraeva, 2014). Ekonomi digital merupakan sesuatu yang sebelumnya tidak ada dalam proses bisnis. Namun demikian, tetap memanfaatkan teknologi sebagai enabler. Ciri khusus ekonomi digital adalah soal pola pikir, yang bukan hanya dari pemikiran out the box, (Kemenkominfo, 2019).

Berdasarkan laporan McKinsey Global Institute pada periode 2014-2017, Indonesia merupakan negara yang mencatat pertumbuhan tercepat di dunia dalam hal adopsi ekonomi digital. Sebagai negara yang mencatat pertumbuhan tercepat dalam mengadopsi ekonomi digital, Indonesia menempati peringkat pertama Indeks pertumbuhan adopsi ekonomi digital dihitung berdasarkan dari tingkat aplikasi digital oleh individu, bisnis, dan pemerintah atas tiga pilar. Ketiga pilar tersebut adalah jangkauan digital (konsumsi data per pengguna), pondasi digital (ketersediaan dan kecepatan unduh), serta nilai digital (penggunaan dalam pembayaran digital atau e-commerce). Skor yang diperoleh Indonesia adalah 99\%, diikuti oleh India 90\%, China 45\%, dan Rusia 44\%, (McKinsey Global Institute, 2019).

Menurut Beske dkk. (2014), penelitian dan aplikasi praktis telah berkembang pesat dalam beberapa dekade terakhir. Untuk menggambarkan bagaimana praktik manajemen rantai pasokan yang berkelanjutan memungkinkan perusahaan untuk mengawasi rantai pasokan mereka dan mencapai keunggulan kompetitif dengan penerapan kemampuan dinamis, Beske dkk.
(2014) melakukan tinjauan literatur yang berfokus pada industri makanan. Selain itu, pendekatan manajemen operasi kuantitatif untuk manajemen distribusi makanan telah ditunjukkan oleh Akkerman dkk. (2010). Dalam kerangka pendekatan pertama yang klasik, ekonomi digital adalah ekonomi yang didasarkan pada teknologi digital dan pada saat yang sama dapat dicirikan secara eksklusif sebagai bidang barang dan jasa elektronik (Nedelkin dkk., 2016). Menurut definisi Bank Dunia, ini adalah sistem hubungan ekonomi, sosial dan budaya yang didasarkan pada penggunaan informasi digital dan teknologi komunikasi (Kusnetsova dkk., 2018).

Di Indonesia, ketahanan pangan dalam Undang-Undang Republik Indonesia Nomor 18 Tahun 2012 Tentang Pangan didefinisikan sebagai kondisi terpenuhinya pangan bagi rumah tangga yang tercermin dari tersedianya pangan yang cukup, baik jumlah maupun mutunya, aman, merata, dan terjangkau. Ketahanan pangan juga disebutkan dalam Undang- Undang tersebut sebagai tanggung jawab pemerintah dan masyarakat. Untuk mencapai ketahanan pangan tersebut pemerintah menyelenggarakan, membina, dan atau mengoordinasikan segala upaya atau kegiatan untuk mewujudkan cadangan pangan nasional, (Undang-Undang RI, 2012). Ketahanan pangan dan ketahanan nasional memiliki hubungan yang erat. Ketahanan pangan merupakan kajian mikro dalam ketahanan nasional. Ketahanan pangan dapat mendukung ketahanan nasional pada gatra ekonomi dengan peningkatan penghasilan yang mendukung gatra ekonomi serta gatra sumber daya alam yang berupa pemanfaatan hasil pertanian yang melimpah.

Penelitian tentang pertanian dan ketahanan pangan yang mengarah pada 
pemanfaatan teknologi masih belum banyak. Penelitian dengan judul Strategi Pengembangan Ketahanan Pangan oleh Nurhadi (2010) menunjukkan adanya pengembangan ketahanan pangan melalui analisis Matrik Internal-Eksternal berupa pengembangan dan peningkatan intensitas jaringan kerjasama, peningkatan kapasitas distribusi pangan, pembangunan sistem cadangan pangan, peningkatan keberdayaan dan partisipasi masyarakat, dan pengembangan diversifikasi dan konsumsi pangan. Begitupun dengan penelitian Jaya (2018) menjelaskan bahwa pemerintah cenderung tidak setuju dan berusaha untuk menurunkan harga komoditas pertanian secara cepat seuai dengan kebijakan-kebijakan yang diambil ketika harga komoditas pertanian naik sejalan dengan visi pemerintah berupa usaha untuk meningkatkan kesejahteraan petani. Hal ini berbanding terbalik dengan persepsi tentang kebijakan harga komoditas pertanian di Indonesia di kalangan petani, bahwa petani merasa tidak memiliki harapan untuk mendapatkan kesejahteraan ekonomi. Selain itu, persepsi petani menunjukkan bahwa sektor pertanian tidak memberikan nasib yang baik untuk dipilih menjadi pekerjaan utama. Hal ini menyebabkan penurunan yang terus menerus pada gairan petani sehingga imbasnya adalah melemahkan ketahanan pangan pada tingkat wilayah.

Sementara itu Fatchiya (2016) pada penelitian yang berjudul Penerapan Teknologi Inovasi Pertanian Dan Hubungannya Dengan Ketahanan Pangan Rumah Tangga Petani menunjukkan bahwa adanya usaha yang dilakukan oleh sebagian besar petani yang memiliki lahan sawah berupa penerapan inovasi teknologi yaitu dengan sistem jajar legowo secara intensif. Selain itu, petani yang memiliki lahan kering cukup intensif dengan penerapan inovasi berupa sistem tumpang sari dan pengolahan pada hasil pertaniannya.

Penelitian Afifah (2018) tentang Penerapan Digital Marketing Dan Pengaruhnya Terhadap Keberhasilan Usaha Mikro, Kecil Dan Menengah Sektor Kreatif Di Indonesia Dan Malaysia menjelaskan bahwa pengetahuan tentang penerapan pemasaran digital merupakan faktor yang paling utama dan berpengaruh besar terhadap keberhasilan adopsi pemasaran digital. Hal ini juga dinilai dapat memberikan manfaat yang lebih bagi masa depan bisnis yang mereka kembangkan.

Melihat beberapa penelitian terdahulu terkait ekonomi pertanian digital yang ditulis oleh Lubis (2010) berisi tentang uraian integrasi efektif Teknologi Informasi dan Komunikasi (TIK) di sektor pertanian akan mengarah pada pertanian berkelanjutan dengan memberikan informasi pertanian yang tepat waktu dan relevan, yang akan memungkinkan petani membuat keputusan yang tepat tentang pertanian untuk meningkatkan produktivitas. TIK dapat sangat meningkatkan aksesibilitas petani ke informasi pasar, input komoditas, tren konsumen, dan informasi pertanian terkait yang berdampak positif pada kualitas dan kuantitas produk mereka. Informasi tentang pemasaran, praktik manajemen baru tanaman dan hewan, hama dan penyakit, ketersediaan transportasi, peluang pemasaran baru, dan harga pasar input dan output pertanian sangat penting untuk ekonomi yang efisien dan produktif.

Pada publikasi ilmiah oleh Warr (2011) yang berjudul Food Security vs. Food SelfSufficiency: The Indonesian Case dijelaskan bahwa ketahanan pangan adalah tujuan sosial yang penting dan bergantung pada pasar pangan internasional untuk memenuhi 
Eko Tulus Wibowo -- Pembangunan Ekonomi Pertanian Digital Dalam Mendukung Ketahanan Pangan (Studi di Kabupaten Sleman: Dinas Pertanian, Pangan, dan Perikanan, Daerah Istimewa Yogyakarta)

kebutuhan populasi Indonesia yang terus bertambah. Strategi yang lebih disukai untuk meningkatkan swasembada adalah mempromosikan peningkatan produktivitas pertanian. Ini mengurangi impor dengan meningkatkan hasil pertanian tetapi melakukannya tanpa menaikkan harga pangan dalam negeri dan tanpa menciptakan konflik antara tujuan tingkat swasembada yang lebih tinggi di satu sisi dan ketahanan pangan dan pengurangan kemiskinan di sisi lain.

Rahim, dkk. (2012) menuliskan bahwa pada bidang ilmu ekonomi pertanian menjelaskan adanya perbedaan harga pada tingkat produsen (petani) dengan tingkat konsumen. Perbedaan ini biasanya diartikan dengan margin pemasaran. Dalam istilah ekonomi, margin pemasaran adalah jumlah selisih atau perbedaan harga beli yang dibayar oleh konsumen dengan harga jual yang diterima oleh produsen. Hal ini dipengaruhi oleh semakin panjangnya rantai pasar yang dilalui atau semakin banyaknya jumlah pedagang, sehingga menyebabkan biaya pemasaran yang semakin besar pula. Hal ini berakibat pada margin pemasaran yang semakin besar sehingga harga jual yang diterima petani menjadi semakin kecil dan dapat mempengaruhi penghasilan serta kesejahteraan petani.

Subejo (2018) menulis tentang Akses, Penggunaan Dan Faktor Penentu Pemanfaatan Teknologi Informasi Dan Komunikasi Pada Kawasan Pertanian Komersial Untuk Mendukung Ketahanan Pangan Di Perdesaan Yogyakarta menjelaskan bahwa untuk mendukung keberlanjutan pertanian komersial perlu adanya kecepatan layanan informasi sehingga dapat memberikan dampak berupa kontribusi pada pencapaian ketahanan pangan yang tinggi. Representasi akses para petani di pedesaan terhadap teknologi informasi dan komunikasi dapat dilihat dari jumlah kepemilikan media TIK yang menjelaskan tentang kapasitas, fleksibilitas dan alternatif masyarakat yang terlibat dalam memanfaatkan dan mengakses berbagai informasi melalui TIK yang dimilikinya. Akibatnya, perlu adanya peningkatan terhadap variasi isi agar lebih komprehensif dengan mencakup semua aspek yaitu teknis produksi, pemasaran, kebijakan, cerita sukses, ketertarikan masyarakat dan pembiayaan pertanian dengan menggunakan media TIK untuk kegiatan pertanian pada kawasan pertanian komersial. Selain itu, kolaborasi antara petani senior bersama petani muda dapat saling bertukar informasi dan melengkapi sesuai dengan karakteristiknya masing-masing, karena petani muda cenderung fokus dalam mengakses media baru yang menyajikan informasi lebih rinci dengan kecepatan tinggi sedangkan petani senior cenderung mengakses banyak media sehingga diperlukan kolaborasi oleh keduanya.

Penelitian ini merupakan penelitian deskriptif dengan pendekatan kualitatif. Menurut Moleong (2011) penelitian kualitatif adalah penelitian yang bermaksud untuk memahami fenomena tentang apa yang dialami oleh subjek penelitian misalnya perilaku, persepsi, motivasi, tindakan dan lain-lain secara holistik dan dengan cara deskripsi dalam bentuk kata-kata dan bahasa, pada suatu konteks khusus yang alamiah dan dengan memanfaatkan berbagai metode alamiah. Penelitian ini mengungkap berbagai informasi kualitatif dengan deskriptif analitis yang diteliti dan penuh makna. Teknik pengumpulan data yang digunakan adalah observasi, wawancara, focus group discussion, dokumentasi dan kepustakaan, serta dokumen dari internet. Dalam penelitian ini informan penelitian adalah orang-orang 
yang memiliki pengetahuan, informasi, pengalaman, serta terlibat langsung dengan permasalahan yang diteliti. Informan pada wawancara adalah 2 orang pegawai di Dinas Pertanian, Pangan, dan Perikanan Kabupaten Sleman, 1 orang pemuda tani dan 1 orang pengembang aplikasi. Informan pada focus group discussion melibatkan 8 orang dari akademisi dan praktisi. Selanjutnya, analisis data yang digunakan adalah kategorisasi data, reduksi data, penyajian data, serta penarikan kesimpulan. Sedangkan, lokasi penelitian dilakukan di Kabupaten Sleman yang lebih mengarah pada Dinas Pertanian, Pangan, dan Perikanan Kabupaten Sleman. Penelitian ini lebih memiliki fokus penelitian pada ekonomi pertanian digital yang diinisiasi dan dikembangkan oleh Dinas Pertanian, Pangan, dan Perikanan Kabupaten Sleman dalam mendukung ketahanan pangan Kabupaten Sleman.

\section{PEMBAHASAN \\ Kabupaten Sleman}

Jika dilihat secara letak, Kabupaten Sleman terletak pada sisi utara Provinsi Daerah Istimewa Yogyakarta. Kabupaten Sleman memiliki topografi wilayah berupa dataran rendah dan dataran tinggi. Ketinggian wilayah Kabupaten Sleman berkisar antara 100 meter hingga 2.500 meter di atas permukaan laut dengan kondisi geografis pada bagian selatan yang relatif datar dan kegunaan utamanya sebagai lahan pertanian, industri, dan permukiman, sedangkan pada bagian utara adalah lereng Gunung Merapi yang memiliki banyak potensi sumber air. Peta Administrasi Kabupaten Sleman dapat dilihat pada gambar 1.

Gambar 1

Peta Administrasi Kabupaten Sleman

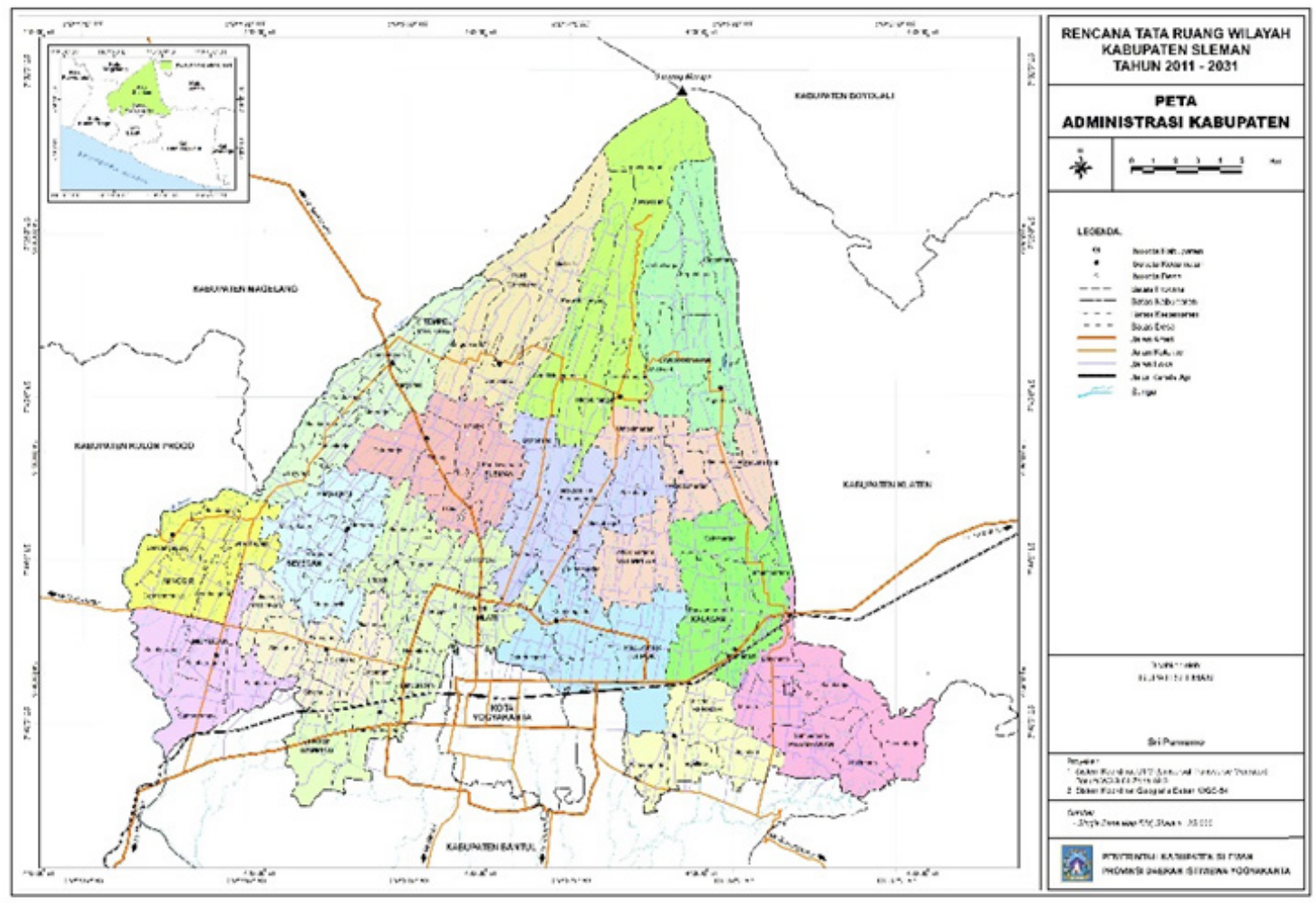

Sumber: BPS Kabupaten Sleman, 2020 
Eko Tulus Wibowo -- Pembangunan Ekonomi Pertanian Digital Dalam Mendukung Ketahanan Pangan (Studi di Kabupaten Sleman: Dinas Pertanian, Pangan, dan Perikanan, Daerah Istimewa Yogyakarta)

Tabel 1

Luas Lahan Menurut Penggunaannya Di Kabupaten Sleman Tahun 2015-2018 (Ha)

\begin{tabular}{|c|c|c|c|c|c|}
\hline No & Jenis Penggunaan & 2015 & 2016 & 2017 & 2018 \\
\hline 1 & Pekarangan / House Compounds & $18.626,87$ & $18.755,32$ & $18.785,96$ & $18.822,55$ \\
\hline 2 & Sawah/Wetland & $24.628,26$ & $24.577,20$ & $24.549,70$ & $24.517,36$ \\
\hline 3 & Tegal/Dry Land & $3.921,69$ & $3.921,69$ & $3.921,69$ & $3.917,45$ \\
\hline 4 & Hutan/Forest & 52,99 & 52,99 & 52,99 & 52,99 \\
\hline 5 & Tanah Tandus dan Semak /Barren and bush & $1.263,84$ & $1.263,85$ & $1.263,84$ & $1.263,84$ \\
\hline \multirow[t]{2}{*}{6} & Lainnya/Others & $8.988,35$ & $8.910,95$ & $8.907,81$ & $8.907,81$ \\
\hline & Jumlah & $57.482,00$ & $57.482,00$ & $57.481,99$ & $57.482,00$ \\
\hline
\end{tabular}

Sumber: Badan Pertanahan Kabupaten Sleman, 2019

Hampir setengah dari luas wilayah Kabupaten Sleman merupakan tanah pertanian yang subur dengan didukung irigasi teknis di bagian barat dan selatan. Keadaan jenis tanahnya dibedakan atas sawah, tegal, pekarangan, hutan, dan lain-lain. Luas lahan menurut penggunaannya dapat dilihat pada tabel 1.

Kabupaten Sleman merupakan salah satu sumber penghasil bahan pokok dari proses produksi pertanian. Hasil pertanian bahan pokok di Kabupaten Sleman meliputi produksi padi, jagung, ubi jalar, dan kedelai. Data luas panen, dan produksi pertanian, terutama padi, jagung, ubi jalar, dan kedelai dapat dilihat pada tabel 2 .

Tabel 2

Luas Panen Dan Produksi Pertanian Bahan Pokok Di Kabupaten Sleman Tahun 2018

\begin{tabular}{llrr}
\hline No & Hasil pertanian & \multicolumn{1}{c}{$\begin{array}{c}\text { Luas } \\
\text { panen } \\
\text { (ha) }\end{array}$} & \multicolumn{1}{c}{$\begin{array}{c}\text { Produksi } \\
\text { (ton) }\end{array}$} \\
\hline 1 & Padi (sawah \& ladang) & 46.820 & $249.878,86$ \\
2 & Jagung & $4.351,8$ & $31.558,47$ \\
3 & Ubi jalar & 106 & 1.728 \\
4 & Kedelai & 156 & 211 \\
\hline
\end{tabular}

Sumber: BPS Kabupaten Sleman, 2019

Selain itu, Kabupaten Sleman memiliki luas panen tanaman beserta produksi sayuran dan buah- buahan semusim yang menjadi komoditi pangan di wilayah Sleman. Adapun luas panen dan produksi sayuran dan buahbuahan dapat dilihat pada tabel 3 .

Tabel 3

Luas Panen Tanaman Sayuran Dan Produksi BuahBuahan Semusim (Ha) Di Kabupaten Sleman Tahun 2018- 2019

\begin{tabular}{llrr}
\hline No & Tahun & Luas panen (ha) & Produksi (ton) \\
\hline 1 & 2016 & 158.494 & $149.220,6$ \\
2 & 2017 & 100.229 & $58.720,5$ \\
3 & 2018 & 50.656 & $60.272,7$ \\
4 & 2019 & 60.500 & $51.889,1$ \\
\hline
\end{tabular}

Sumber: BPS Kabupaten Sleman, 2020

Jumlah penduduk Kabupaten Sleman tahun 2019 adalah 1.075.575. Sektor yang paling banyak menyerap tenaga kerja adalah kategori perdagangan yang menyerap 144.067 tenaga kerja atau 22,17 persen dari penduduk yang bekerja di Kabupaten Sleman. Selanjutnya adalah industri pengolahan yang menyerap 104.806 tenaga kerja (16,13 persen), diikuti kategori akomodasi dan rumah makan yang menyerap 72.841 tenaga kerja (11,21 persen) dan kategori pertanian masih menyerap 10,94 persen tenaga kerja di Kabupaten Sleman. Sedangkan 12 kategori lainnya menyerap tenaga kerja masing-masing di bawah 10 persen. Adapun persentase lapangan pekerjaan utama di Kabupaten Sleman tahun 2019 dapat dilihat pada gambar 2. 
Gambar 2

Persentase Lapangan Pekerjaan Utama Di Kabupaten Sleman Tahun 2019

Persentase Lapangan Pekerjaan Utama di Kabupaten Sleman Tahun 2019

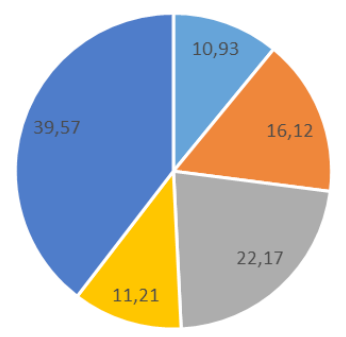

- Pertanian

- Industri Pengolahan

- Perdagangan

- Akomodasi \& Makan Minum

- Lainnya

Sumber: BPS Kabupaten Sleman, 2019 dan Olahan peneliti, 2020

Kondisi geografis Kabupaten Sleman yang berupa lahan subur dapat memberikan hasil pangan yang melimpah bagi penduduknya. Ada beberapa bagian di wilayah Sleman memiliki potensi produksi pangan sehingga ini akan berdampak pada tercukupinya ketersediaan pangan. Di samping hal tersebut, Kabupaten Sleman tidak memiliki kondisi geografis yang terjal. Dataran tinggi dan dataran rendah tergabung sedemikian rupa sehingga membuat akses terhadap lokasi tertentu tidak terlalu sulit dibandingkan kabupaten lain seperti Kulon Progo dan Gunung Kidul. Artinya, hal ini memudahkan penduduk lebih fleksibel dalam jangkauan transportasi yang erat kaitannya dengan distribusi produk pertanian. Begitu pula dengan letak geografis Kabupaten Sleman yang berbatasan langsung dengan empat kabupaten/ kota lainnya di Daerah Istimewa Yogyakarta serta berbatasan langsung dengan Propinsi Jawa Tengah.

Kedua hal di atas berkaitan erat dengan sumber daya alam yang menjadi dukungan dalam rangka usaha tani guna menciptakan ketahanan pangan. Hal ini dapat dilihat dari

terpenuhinya kebutuhan air di Kabupaten Sleman. Kabupaten Sleman memiliki banyak sumber mata air yang dimanfaatkan untuk irigasi pertanian. Selain itu, Kabupaten Sleman juga mendapat aliran air dari Gunung Merapi serta Gunung Merbabu melalui selokan mataram. Kabupaten Sleman sendiri memiliki Dewan Ketahanan Pangan (DKP) yang diketuai langsung oleh Bupati yang terdiri dari kelompok kerja ahli berupa praktisi/ dosen dan kelompok kerja teknis berupa satuan kerja, dinas dan instansi terkait yang memiliki peran intensif dalam melakukan koordinasi, kajian dan diskusi sebagai upaya penguatan ketahanan pangan di Kabupaten Sleman. Selain itu, obyek yang menjadi penelitian adalah Dinas Pertanian, Pangan Dan Perikanan Kabupaten Sleman. Dinas Pertanian, Pangan dan Perikanan merupakan salah satu lembaga di Pemerintah Kabupaten Sleman yang melaksanakan urusan pemerintahan dan tugas pembantuan di bidang pertanian, bidang pangan dan bidang perikanan.

\section{Ekonomi Pertanian Digital}

Ekonomi pertanian digital semakin terus berkembang. Konsep yang diadopsi dari ekonomi pertanian ini dikombinasikan dengan kemajuan teknologi ini dalam perkembangannya dilihat dari kebijakan pemerintah pada bidang pertanian berbasis digital masih belum banyak dijumpai terutama pada sektor hilir. Kebijakan pemerintah berbasis digital masih pada pertanian sektor hulu yaitu Peraturan Menteri Pertanian Republik Indonesia Nomor 41/Permentan/ OT.140/3/2014 tentang Pedoman Perencanaan Pembangunan Pertanian Berbasis e-Planning yang memiliki ruang lingkup yang mencakup pengelolaan e-Planning, penyusunan dan 
Eko Tulus Wibowo -- Pembangunan Ekonomi Pertanian Digital Dalam Mendukung Ketahanan Pangan (Studi di Kabupaten Sleman: Dinas Pertanian, Pangan, dan Perikanan, Daerah Istimewa Yogyakarta)

penilaian proposal, pengoperasian aplikasi e-Proposal, dan pengelolaan Sistem Informasi Perencanaan Kawasan Pertanian (SIKP).

Ekonomi pertanian digital selain meningkatkan penghasilan juga dapat mendorong pembangunan pertanian serta mendukung petani bersaing secara global. Seperti yang disampaikan Bahua (2016) bahwa adanya pembangunan pertanian yang lebih berpihak kepada petani memberikan dampak pada kepercayaan dalam diri petani untuk berusaha meningkatkan produktivitas usaha taninya. Dengan sistem agribisnis dan agroindustri yang berorientasi terhadap pendidikan non formal menunjukkan adanya tantangan yang ditujukan pada petani dalam menghadapi persaingan pada pasar global. Begitupun dengan perkembangan teknologi pertanian yang dapat menjadi solusi dalam pembangunan pertanian.

Ekonomi pertanian digital merupakan kelanjutan dari ekonomi pertanian yang dimanfaatkan dengan menggunakan handphone hingga smartphone yang penggunaannya berupa pesan singkat, panggilan (telepon), hingga aplikasi sosial media berupa Whatsapp, Facebook, Instagram, bahkan aplikasi khusus lainnya.
Hal ini juga sejalan dengan observasi yang dilakukan di media sosial berupa Facebook dan Instagram. Facebook dan Instagram kini menjadi wadah untuk ajang jual beli produk pertanian. Pada media sosial facebook menyediakan layanan halaman Marketplace yang tampilannya berupa produk hasil pertanian yaitu sayuran, bahkan ada pula pupuk hingga alat mesin pertanian. Hal ini memudahkan konsumen yang masih belajar era digital dalam memanfaatkan ekonomi pertanian digital. Tampilan halaman marketplace pada facebook dengan pencarian 'Sayuran' di wilayah Sleman dapat dilihat pada gambar 3.

Selain itu, pada wilayah Sleman juga ditemukan pemanfaatan jual beli produk pertanian melalui Tokopedia. Konsumen dapat menentukan pilihan produk pertanian sesuai lokasi terdekat untuk bisa mendapatkannya. Platform yang didirikan sejak tahun 2009 ini memang belum banyak dikenal dalam hal bisnis pertanian. Namun, beragam produk hasil pertanian sudah banyak dipromosikan melalui website maupun aplikasi ini. Adapun tampilan halaman Tokopedia dengan pencarian 'Sayur' di wilayah Kabupaten Sleman dapat dilihat pada gambar 4 .

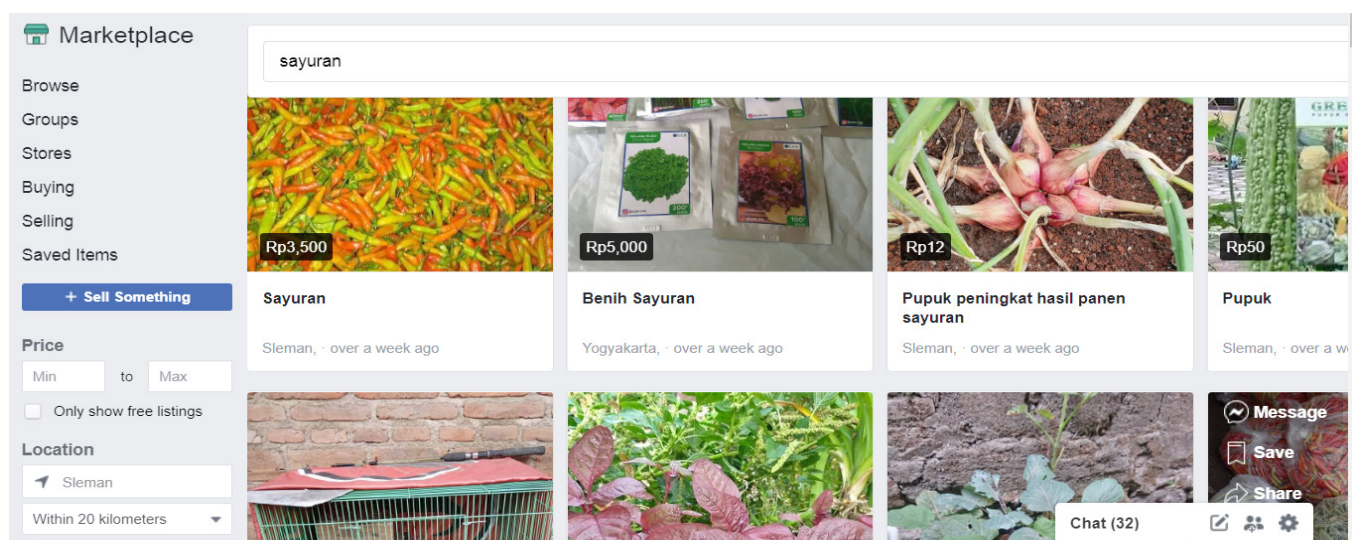

Sumber: Facebook, 2020 


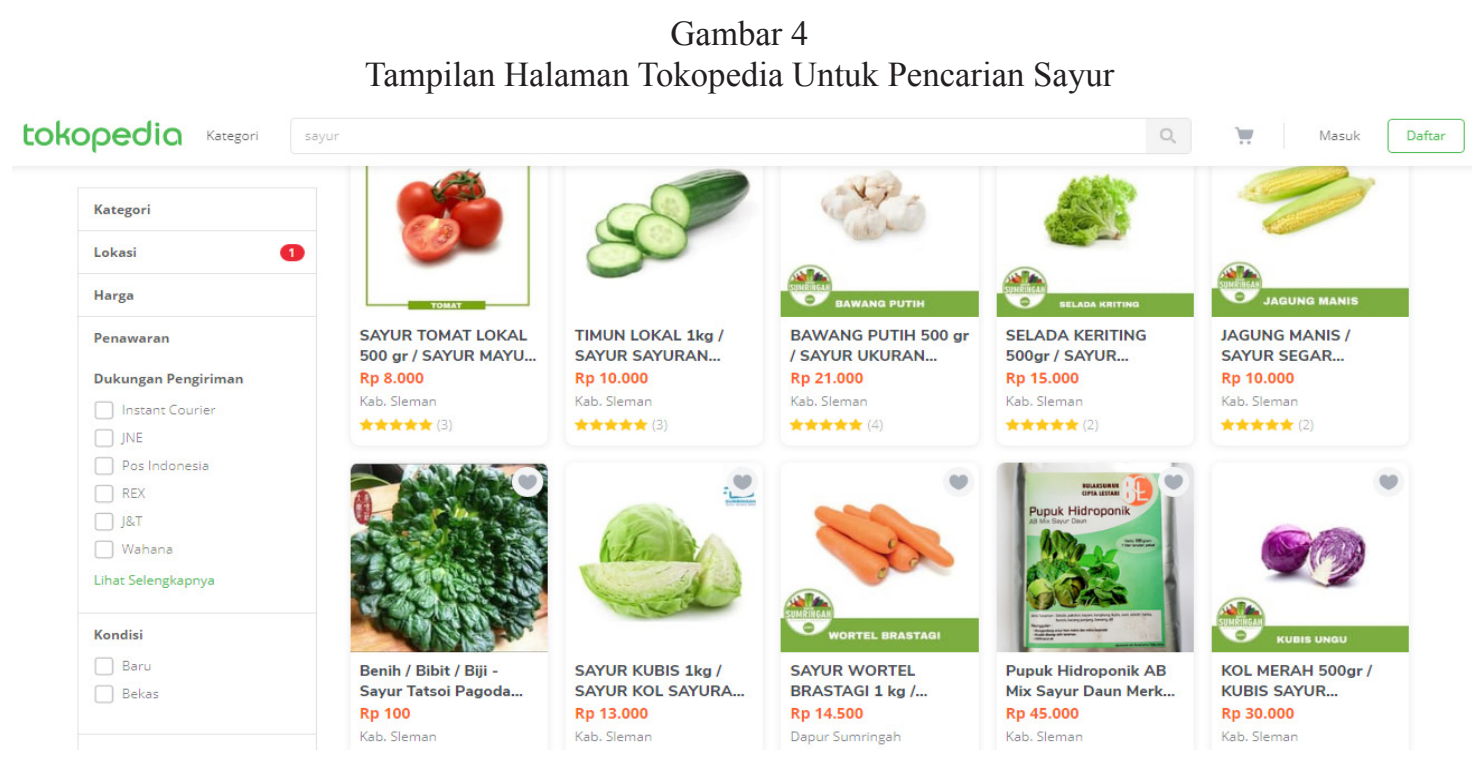

Sumber: Tokopedia, 2020

\section{Permasalahan Dalam Ekonomi Pertanian} Digital

Terlepas dari kemajuan teknologi informasi dan komunikasi, ekonomi pertanian digital memunculkan ragam permasalahan. Permasalahan dalam pengembangan ekonomi pertanian digital salah satunya adalah ketersediaan produk pertanian yang tidak terpenuhi. Meskipun jangkauannya luas, pemenuhan kebutuhan belum tentu tercapai. Konsumen mayoritas berkeinginan untuk segera mendapatkan produk pertanian, namun kertersediaan produk pertanian yang belum tentu ada menjadi kendala tersendiri. Hal ini berkorelasi dengan kekurangan ekonomi pertanian digital yang dalam pelaksanaannya kurang maksimal dalam mengelola sumber daya manusia. Petani saat ini masih fokus pada proses budidaya, sehingga belum memahami konsep ekonomi pertanian digital.

Seperti yang disampaikan Durou, dkk. (2016) bahwa sumber daya manusia perlu lebih preventif berkenaan dengan transformasi digital karena memainkan peran penting dalam membentuk identitas digital. Ini adalah tantangan dan kompleksitas nyata untuk merencanakan kemampuan tenaga kerja di masa depan dalam ekonomi digital; seperti kemampuan untuk mengintegrasikan orang yang tepat serta mendapatkan kompetensi digital baru untuk dapat mendorong transformasi. Selain itu, petani yang belum mampu mengelola aplikasi sehingga belum tentu adanya udpate produk hasil pertanian beserta harga yang ditawarkan. Petani pada umumnya hanya fokus pada proses produksi terkadang melupakan proses hilir yang sebenarnya cakupannya sangat luas. Secara teknis, petani belum mampu memperkirakan estimasi dengan tepat produk pertanian yang dihasilkan sehingga tidak dapat merekapitulasi hasil produk pertanian.

Jika dilihat dari segi konsumen, meskipun dinilai mudah dalam menggunakan smartphone khususnya kalangan muda, namun akses terhadap ekonomi pertanian digital berupa website maupun aplikasi masih minim. Artinya, aplikasi yang sesuai untuk kebutuhan produk pertanian masih belum dapat dijumpai secara cepat. Hal ini berkaitan dengan permasalahan tentang informasi kebutuhan pertanian. Dalam 
Eko Tulus Wibowo -- Pembangunan Ekonomi Pertanian Digital Dalam Mendukung Ketahanan Pangan (Studi di Kabupaten Sleman: Dinas Pertanian, Pangan, dan Perikanan, Daerah Istimewa Yogyakarta)

dunia pertanian sangat kompleks, mulai dari budidaya yang membutuhkan pupuk maupun alat mesin pertanian yang nantinya menghasilkan panen dalam bentuk produk hasil pertanian. Dalam ekonomi digital yang global, kebutuhan konsumen menjadi beragam sehingga menimbulkan kurang tepat dan kurang cukupnya kebutuhan konsumen. Masih dalam masalah yang dihadapi konsumen, kebutuhan produk pertanian diinginkan secara cepat, namun respon petani yang kurang cepat menyebabkan kebutuhan produk pertanian menjadi terkendala. Di sisi lain, saat ini semakin banyak petani yang sudah menginjak usia tua. Sedangkan minat petani muda mulai menurun seiring berkembangnya pilihan lapangan kerja lainnya. Hal ini membuat adanya perbedaan jarak antara petani tua dan petani muda semakin tinggi sehingga memunculkan dampak berupa kurang tertariknya dalam memanfaatkan ekonomi pertanian digital.

Dari hasil analisis dilihat dari segi kesiapan produk pertanian, kendala yang muncul adalah petani belum memiliki dukungan sarana prasarana yang sesuai kebutuhan. Dalam menunjang proses menuju ekonomi pertanian digital dibutuhkan sarana prasarana selain smartphone tidak menutup kemungkinan adanya kebutuhan lain. Kesiapan petani dalam menyambut era digital masih sangat minim dan kurang maksimal dalam segi kesiapan secara teknis. Petani sebagai produsen menilai bahwa ekonomi pertanian digital memiliki proses yang rumit mulai dari pengambilan gambar, input pada aplikasi, hingga menetapkan harga. Hal ini akan menurunkan ketertarikan petani. Hal ini juga selaras dengan kebutuhan petani dalam memanfaatkan ekonomi pertanian digital berupa sarana prasarana berupa platform pembayaran yang digunakan. Dengan adanya ekonomi pertanian digital, tentunya petani juga akan melakukan transaksi dalam bentuk digital. Petani dinilai masih belum tertarik pada ekonomi pertanian digital berupa aplikasi. Terkadang, petani masih belum dapat melihat kebutuhan yang sesuai meskipun sudah memiliki smartphone.

Berdasarkan observasi, dukungan sarana dan prasarana lain yang menjadi penghambat adalah akses terhadap internet yang masih menemui kelemahan pada beberapa tempat, sehingga kemampuan petani untuk memanfaatkan ekonomi pertanian digital menjadi berkurang. Kabupaten Sleman memiliki kondisi geografis yang berupa dataran tinggi yang jauh dari pusat pemancar jaringan sehingga menyebabkan akses internet menjadi kurang kuat. Jenis permasalahan terkait pengembangan ekonomi pertanian digital dapat dilihat pada tabel 4 .

\section{Manfaat Ekonomi Pertanian Digital}

Kemajuan teknologi informasi membuat informasi dapat diakses secara global. Teknologi informasi dan komunikasi berupa ekonomi pertanian digital memberikan kemudahan dalam mendapatkan informasi bagi masyarakat untuk mengetahui hasil produk pertanian. Dari sisi petani, ekonomi pertanian digital sebagai sarana untuk memasarkan hasil produksinya. Hal ini juga sebanding lurus dengan manfaat yang diperoleh konsumen. Ekonomi pertanian digital sebagai akses untuk mendapatkan informasi ketersediaan hasil produksi maupun harga sehingga mudah dan cepat dalam mendapatkan produk pertanian.

Dengan memanfaatkan aplikasi ataupun website bahkan media sosial lebih memudahkan pengguna untuk mendapatkan produk pertanian dengan jarak yang dapat dijangkau. 
Tabel 4

Jenis Permasalahan Terkait Pengembangan Ekonomi Pertanian Digital

\begin{tabular}{|c|c|c|c|}
\hline Jenis permasalahan & Keterangan & Sifat & Alternatif strategi \\
\hline $\begin{array}{l}\text { Kepemilikan/ akses } \\
\text { terhadap ekonomi } \\
\text { pertanian digital }\end{array}$ & $\begin{array}{l}\text { Petani umumnya sudah menggunakan } \\
\text { smatrphone, namun belum memanfaatkan } \\
\text { untuk ekonomi pertanian digital }\end{array}$ & Internal & $\begin{array}{l}\text { - Pelatihan tentang ekonomi } \\
\text { pertanian digital } \\
\text { - } \quad \text { Program Magang pada } \\
\text { instansi/ perusahaan }\end{array}$ \\
\hline $\begin{array}{l}\text { Literasi ekonomi } \\
\text { pertanian digital }\end{array}$ & $\begin{array}{l}\text { Pemahaman petani yang masih kurang } \\
\text { terhadap penggunaan dan pengelolaan } \\
\text { ekonomi pertanian digital dalam } \\
\text { bentuk aplikasi, website, maupun } \\
\text { media sosial berupa Whatsapp, } \\
\text { Facebook, dan Instagram. Digitalisasi } \\
\text { dinilai masih rumit, sehingga belum } \\
\text { memunculkan ketertarikan. } \\
\text { Petani belum dapat mengupdate hasil } \\
\text { produk pertanian dan masih pada fokus } \\
\text { budidaya. }\end{array}$ & Internal & $\begin{array}{l}\text { Pelatihan tentang ekonomi } \\
\text { pertanian digital } \\
\text { Pelatihan tentang } \\
\text { tata cara update hasil } \\
\text { produk pertanian dan } \\
\text { keuntungannya }\end{array}$ \\
\hline $\begin{array}{l}\text { Ketersediaan aplikasi } \\
\text { digital pertanian }\end{array}$ & $\begin{array}{l}\text { Konsumen memiliki smartphone, } \\
\text { namun masih sedikit aplikasi yang dapat } \\
\text { dimanfaatkan sesuai kebutuhan. }\end{array}$ & Eksternal & $\begin{array}{l}\text { Menjalin kemitraan dengan } \\
\text { Kementerian Komunikasi dan } \\
\text { Informatika (Kemkominfo), } \\
\text { Kementerian Pertanian, } \\
\text { perusahaan, serta pengembang } \\
\text { aplikasi/ developer }\end{array}$ \\
\hline $\begin{array}{l}\text { Kelengkapan } \\
\text { informasi }\end{array}$ & $\begin{array}{l}\text { Informasi pasar kurang sesuai dengan } \\
\text { kebutuhan petani maupun konsumen pada } \\
\text { ekonomi pertanian digital sehingga perlu } \\
\text { informasi yang beragam. }\end{array}$ & Eksternal & $\begin{array}{l}\text { Pelatihan dalam memberikan } \\
\text { informasi pasar }\end{array}$ \\
\hline $\begin{array}{l}\text { Kecepatan respon } \\
\text { oleh developer dan } \\
\text { user }\end{array}$ & $\begin{array}{l}\text { Konsumen yang menginginkan produk } \\
\text { pertanian kurang mendapatkan respon } \\
\text { yang cepat dari produsen, begitu pula } \\
\text { konsumen yang terkadang memiliki } \\
\text { respon yang lambat. }\end{array}$ & Eksternal & $\begin{array}{l}\text { Pelatihan tentang kecepatan } \\
\text { menanggapi respon dan } \\
\text { memanfaatkan peluang }\end{array}$ \\
\hline $\begin{array}{l}\text { Dukungan sarana } \\
\text { dan prasarana } \\
\text { (infrastuktur) }\end{array}$ & $\begin{array}{l}\text { - Petani belum memiliki dukungan } \\
\text { sarana prasarana yang memadai berupa } \\
\text { smartphone yang canggih, handycamp } \\
\text { serta laptop, bahkan dukungan lain } \\
\text { berupa transaksi melalui e-money } \\
\text { - Jaringan telekomunikasi masih terbatas }\end{array}$ & Eksternal & $\begin{array}{l}\text { Kemitraan dengan } \\
\text { Dinas atau Kementerian } \\
\text { Pertanian dalam subsidi } \\
\text { dan penggunanaan sarana } \\
\text { prasarana terkait } \\
\text { Kemitraan dengan } \\
\text { Kemkominfo dalam } \\
\text { dukungan jaringan } \\
\text { internet. }\end{array}$ \\
\hline
\end{tabular}

Sumber: Olahan peneliti, 2020

Hal ini dapat dilihat dari pemanfaatan ekonomi pertanian digital yang dapat memilih lokasi keberadaan terdekat antara produsen dan konsumen untuk dapat bertransaksi melalui digital. Kendati demikian, dengan adanya digitalisasi ini, ekonomi pertanian digital dapat diartikan sebagai proses transaksi tanpa mengenal jarak. Melalui digitalisasi secara global membuat produsen maupun konsumen dapat saling terhubung dengan jarak yang jauh.
Selain itu, keuntungan yang dapat dirasakan berupa efisiensi waktu yang didapatkan oleh konsumen dalam bertransaksi bisnis. Waktu tunggu untuk kedatangan pesanan produk pertanian menjadi lebih singkat. Begitu pula dengan waktu transaksi baik konsumen maupun produsen dapat dilakukan kapanpun sesuai keinginan dan kebutuhan konsumen terhadap produsen. Adanya konsep ekonomi pertanian digital membuat harga pasar menjadi 
Eko Tulus Wibowo -- Pembangunan Ekonomi Pertanian Digital Dalam Mendukung Ketahanan Pangan (Studi di Kabupaten Sleman: Dinas Pertanian, Pangan, dan Perikanan, Daerah Istimewa Yogyakarta)

lebih transparan. Artinya, harga jual dan harga beli tidak memiliki jarak yang tinggi, sehingga, petani dapat menentukan harga sesuai kualitas produk pertanian begitu pula dengan konsumen yang akan mendapatkan harga tidak terlalu tinggi (sebanding dengan kualitas produk pertanian). Pasar pertanian cenderung memiliki segmentasi pasar yang kurang heterogen. Konsumen yang membutuhkan skala dalam jangka besar lebih memilih relasi dengan produsen besar, sehingga didominasi oleh kelompok mayoritas. Ekonomi pertanian digital dapat mempertemukan produsen dan konsumen sesuai kemampuannya. Hal ini dapat memberikan kesempatan yang lebih luas bagi produsen untuk menemukan konsumen yang besar, sehingga pasar menjadi lebih heterogen serta segmentasi pasar tidak hanya didominasi oleh produsen dan konsumen besar saja. Pada era seperti saat ini, petani harus mampu mengimbangi kemajuan teknologi dan informasi. Ekonomi pertanian digital dapat dipandang sebagai sebuah ilmu baru yang dalam pemanfaatannya sebagai ajang belajar dalam pesatnya perkembangan teknologi informasi dan komunikasi. Dengan adanya ekonomi pertanian digital, tidak menutup kemungkinan muncul inovasi baru dalam bidang pertanian. Manfaat TIK dalam mendukung ekonomi pertanian digital dapat dilihat pada tabel 5 .

\section{Strategi Pembangunan Ekonomi Pertanian Digital}

Dalam pelaksanannya, ekonomi pertanian digital dinilai belum banyak dimanfaatkan sehingga perlu adanya strategi dalam pengembangannya. Bimbingan Teknis (Bimtek) bertujuan untuk mengenalkan ekonomi pertanian digital dalam bentuk aplikasi maupun website. Ini menjadi salah satu cara dalam rangka pengembangan ekonomi pertanian digital (Kementan, 2015). Dari hasil analisis peneliti, dengan adanya

Tabel 5

Manfaat TIK Dalam Mendukung Ekonomi Pertanian Digital

\begin{tabular}{|c|c|c|}
\hline Jenis manfaat & Bentuk dukungan & Tingkat pemanfaatan \\
\hline $\begin{array}{l}\text { Kecepatan } \\
\text { transaksi }\end{array}$ & $\begin{array}{l}\text { Memudahkan petani dalam memasarkan produk pertanian, } \\
\text { begitu pula dengan konsumen yang mudah memilih } \\
\text { Memudahkan mengetahui sarana prasarana dalam produksi } \\
\text { pertanian, informasi cuaca, ketersediaan benih, kebutuhan } \\
\text { pupuk (untuk proses budidaya) }\end{array}$ & $\begin{array}{l}\text { - Intensif } \\
\text { - Kurang intensif }\end{array}$ \\
\hline $\begin{array}{l}\text { Menghilangkan } \\
\text { hambatan jarak }\end{array}$ & $\begin{array}{l}\text { - Mengetahui jarak terdekat antara produsen dan konsumen } \\
\text { - } \text { - Tidak diperukan jarak yang jauh } \\
\text { membutuhkan biaya }\end{array}$ & $\begin{array}{l}\text { - Intensif } \\
\text { - Sangat intensif } \\
\text { Intensif }\end{array}$ \\
\hline $\begin{array}{l}\text { Menghilangkan } \\
\text { hambatan waktu }\end{array}$ & $\begin{array}{l}\text { - Mempersingkat waktu untuk mendapatkan produk pertanian } \\
\text { - Dapat bertransaksi dengan waktu yang lebih fleksibel/ } \\
\text { kapanpun. }\end{array}$ & $\begin{array}{l}\text { - Intensif } \\
\text { - Sangat intensif }\end{array}$ \\
\hline $\begin{array}{l}\text { Membuat } \\
\text { harga menjadi } \\
\text { transparan }\end{array}$ & $\begin{array}{l}\text { - Memudahkan mengetahui harga pasar } \\
\text { - Harga pasar menjadi lebih transparan antara produsen dan } \\
\text { konsumen/ tidak perlu melalui makelar. }\end{array}$ & $\begin{array}{l}\text { - Intensif } \\
\text { - Intensif }\end{array}$ \\
\hline $\begin{array}{l}\text { Mengurangi } \\
\text { segmentasi } \\
\text { produsen dan } \\
\text { konsumen }\end{array}$ & $\begin{array}{l}\text { Transaksi produsen dan konsumen dari berbagai level/ } \\
\text { skala transaksi (produsen kecil dengan konsumen besar atau } \\
\text { sebaliknya) }\end{array}$ & - Intensif \\
\hline
\end{tabular}

Sumber: Olahan peneliti, 2020 
Bimtek mampu meningkatkan pemahaman tentang ekonomi pertanian digital dengan cara saling bertukar informasi dan pengalaman satu sama lain.

Selain itu, agar tercapainya pemahaman tentang ekonomi pertanian digital, memberikan dorongan semangat dan motivasi merupakan hal yang penting. Motivasi dapat meningkatkan keinginan petani agar mampu memahami ekonomi pertanian digital. Hal yang sama juga mampu diterapkan melalui penyuluhan terhadap petani maupun masyarakat. Penyuluhan dengan menjelaskan berbagai manfaat ekonomi pertanian digital dapat menjadi salah satu strategi pengembangan.

Kendati demikian, perlu adanya starategi lain. Secara teknis, pembuatan kalender yang mengandung tema prosedur penggunaan aplikasi dapat meningkatkan pemahaman petani maupun masyarakat. Selain menimbulkan daya tarik, kalender yang hampir dilihat setiap hari akan semakin menambah wawasan dan pengembangan dalam pembelajaran. Dalam membangun sumber daya mausia yang unggul, pembelajaran dapat didorong melalui kegiatan nyata sehingga ilmu yang dimiliki dapat di aplikasikan secara langsung di lapangan. Pembelajaran ini dapat berupa program magang pada perusahaan start- up swasta yang berbasis ekonomi pertanian digital berupa aplikasi maupun pada Dinas serta Kementerian. Adapun Kementerian yang terkait adalah Kementerian Pertanian serta Kementerian Komunikasi dan Informatika. Hal ini memberikan dampak kepada petani terlebih petani yang masuk dalam golongan petani muda berupa penguasaan materi dalam mengembangkan ekonomi pertanian digital hingga mampu menciptakan inovasi. Strategi pengembangan ekonomi pertanian digital dapat dilihat pada tabel 6 .

\section{Ekonomi Pertanian Digital Yang Terbangun}

Ekonomi pertanian digital dapat dibangun dengan beragam bentuk. Hingga saat ini, ekonomi pertanian digital dapat berupa aplikasi maupun website. Program yang diinisiasi Dinas Pertanian, Pangan, dan Perikanan Kabupaten Sleman menunjukkan adanya ekonomi pertanian digital yang telah terbangun yaitu website Portalsayur.com dan Cobain Susu.

Pertama, website Portalsayur.com. Website bernama Portalsayur.com ini menyediakan informasi tentang beragam produk pertanian. Secara prinsip, website ini memberikan kemudahan petani dalam memperbaharui hasil pertanian dan konsumen

Tabel 6

Strategi Pengembangan Ekonomi Pertanian Digital

\begin{tabular}{|c|c|c|}
\hline Jenis strategi & Kegiatan & Aktor yang terlibat \\
\hline Bimbingan Teknis & $\begin{array}{l}\text { Pengenalan dan Pelatihan tentang ekonomi } \\
\text { pertanian digital }\end{array}$ & $\begin{array}{l}\text { Dinas Pertanian, Pangan, dan } \\
\text { Perikanan Kab. Sleman serta praktisi }\end{array}$ \\
\hline Penyuluhan dan sosialisai & $\begin{array}{l}\text { Bimbingan dan dukungan motivasi untuk } \\
\text { mengembangkan ekonomi pertanian digital }\end{array}$ & $\begin{array}{l}\text { Dinas Pertanian, Pangan, dan } \\
\text { Perikanan Kab. Sleman, developer } \\
\text { aplikasi, Kemkominfo }\end{array}$ \\
\hline Pembuatan Kalender & $\begin{array}{l}\text { Kalender dengan tema ekonomi pertanian } \\
\text { digital }\end{array}$ & $\begin{array}{l}\text { Dinas Pertanian, Pangan, dan } \\
\text { Perikanan Kab. Sleman }\end{array}$ \\
\hline Program magang & $\begin{array}{l}\text { Tokoh pemuda tani magang pada Dinas, } \\
\text { Kementerian, perusahaan berbasis ekonomi } \\
\text { pertanian digital, bahkan pada developer } \\
\text { aplikasi }\end{array}$ & $\begin{array}{l}\text { Dinas Pertanian, Pangan, dan } \\
\text { Perikanan Kab. Sleman, developer } \\
\text { aplikasi, kelompok tani, Kemkominfo }\end{array}$ \\
\hline
\end{tabular}

Sumber: Olahan peneliti, 2020 
Eko Tulus Wibowo -- Pembangunan Ekonomi Pertanian Digital Dalam Mendukung Ketahanan Pangan (Studi di Kabupaten Sleman: Dinas Pertanian, Pangan, dan Perikanan, Daerah Istimewa Yogyakarta)

yang menginginkan produk pertanian. Dari data statistik yang dirangkum peneliti, website ini termasuk website yang berhasil dimanfaatkan pengguna baik dalam proses ekonomi pertanian digital maupun hanya sekedar mencari informasi. Dalam satu bulan, jumlah kunjungan yang melihat website sebanyak 236 kali, pencarian terhadap Google Maps sebanyak 152 kali, viewers website sebanyak $2.130 \mathrm{kali}$, dan viewers foto produk pertanian sebanyak 2.120 kali dengan sebaran pengguna pada wilayah Sleman utara dan Sleman selatan. Data- data tersebut menunjukkan bahwa indikator keberhasilan website adalah besaran jumlah pengunjung website.

Secara konseptual, Portalsayur.com memiliki tujuan agar konsumen dapat melihat dan memilih produk hasil pertanian dengan cara menyajikan data produk pertanian beserta harganya untuk dipesan. Dari hasil analisis, Portalsayur.com memiliki Strength (kekuatan) dalam mengelola Portalsayur.com adalah keahlian dalam bidang teknologi dan informasi terkait pengembangan website, selain itu sang owner memiliki pengetahuan khusus dalam mengelola produk pertanian pada saat pascapanen hingga distribusi produk pertanian. Hal ini berbanding lurus dengan Opportunity (peluang) yang ada dan dimanfaatkan menjadi kesempatan berharga oleh pengembang website. Hal ini dapat dilihat dari adanya peluang dalam pemenuhan kebutuhan sayuran bagi supermarket maupun kebutuhan sayuran untuk restoran maupun warung makan. Kelimpahan panen pada suatu tempat dapat disiasati dengan distribusi produk pertanian ke tempat lainnnya yang membutuhkan. Dengan adanya sentuhan teknologi, maka ekonomi pertanian digital merupakan solusi yang tepat untuk mendukung kelancaran memanfaatkan peluang. Bahkan, hal ini dapat dikembangkan dengan memperluas jangkauan dalam mendistribusikan produk pertanian kepada konsumen baik dalam kabupaten hingga lintas kabupaten/ kota.

Kendati demikian, Portalsayur.com yang mengalami upgrade (peningkatan) tampilan website tahun 2018 ini, memiliki kelemahan dan ancaman dalam berkembang. Weakness (kelemahan) Portalsayur.com yaitu masih belum mampu menyediakan pelayanan secara maksimal melaui website, sehingga pengguna harus menghubungi melalui Whatsapp untuk konfirmasi pemesanan. Selain itu, Portalsayur.com belum tersedia dalam bentuk aplikasi yang dapat diunduh. Sejalan dengan hal tersebut, Threat (ancaman) yang menyebabkan lambatnya pelayanan melaui website adalah adanya virus pengganggu yang berupa program yang dirancang untuk merusak website atau yang sering disebut malware melalui jaringan internet sehingga membuat kemampuan website menjadi melambat. Hal ini tak dapat dipungkiri mengingat pasar online yang semakin kompetitif sehingga dapat menurunkan eksistensi website. Tampilan website Portalsayur.com dapat dilihat pada gambar 5.

Kedua, pemasaran online 'Cobain Susu'. Usaha yang produk utamanya adalah susu segar ini memiliki lokasi yang menjadi tempat stok sebelum terjual berada tidak jauh dari Jl. Kaliurang Km 13,5. Lokasi yang termasuk pada wilayah Kabupaten Sleman bagian utara ini terkadang jarang diminati kecuali oleh masyarakat sekitar. Oleh karena itu, penggunaan media online sebagai sarana pemasaran menjadi inovasi yang dikembangkan. Saat ini, bisnis 'Cobain Susu' telah akrab di mata masyarakat dengan pemasarannya melalui instagram@ 
Gambar 5

Tampilan Website Portalsayur.com

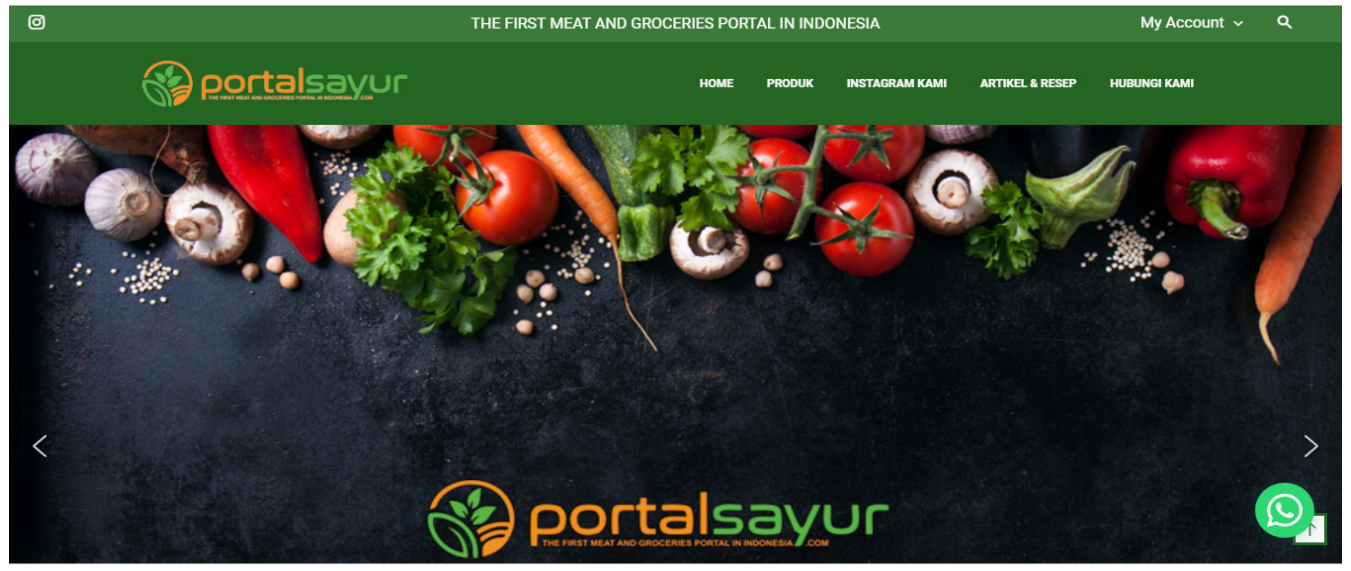

Sumber: Olahan peneliti, 2020

cobainsusu_serta aplikasi Go Food juga dapat ditemukan dengan pencarian Cobain Susu. Untuk memenuhi kebutuhan konsumen, owner 'Cobain Susu' juga menggunakan media sosial Whatsapp untuk menjawab pertanyaanpertanyaan pelanggan. Jika dilihat dari analisis SWOT, 'Cobain Susu' ini memiliki Strenght (kekuatan) berupa jaringan kerjasama dengan produsen susu serta mampu dikembangkan dengan inovasi berupa tambahan varian rasa sehingga produk yang dihasilkan memiliki rasa yang beragam.

Namun, Weakness (kelemahan) yang muncul adalah media pemasaran online yang digunakan masih memanfaatkan Go Food melalui aplikasi yang dimiliki Go-jek. Hal ini membuat penentuan harga masih dikuasai oleh pihak Go Food, artinya harga susu ini hanya bisa ditentukan dari harga beli ditambah keuntungan yang ingin diperoleh. Hal ini dikarenakan pihak Go Food mengambil keuntungan tiap transaksi sesuai dengan jarak pemesanan 'Cobain Susu' kepada konsumen, sehingga biaya ongkos kirim oleh ojek online beserta pajak transaksi yang sekaligus keuntungan aplikasi Go Food dibebankan kepada konsumen.

Jika dilihat dari segi Opportunity (peluang), penjualan secara online atau pemanfaatan ekonomi pertanian digital ini memberikan peluang lebih besar dalam mengembangkan pasar. Artinya, konsumen yang menginginkan susu dapat memesan melalui Go Food dan tidak terhambat oleh jarak dan waktu. Proses pemesanan yang dapat dilakukan secara cepat dan proses distribusi juga menjadi lebih fleksibel. Selain itu, peluang mendapatkan konsumen yang tergolong masyarakat kelas menengah ke atas menjadi semakin terbuka lebar. Selain itu, Threat (ancaman) yang muncul dalam ekonomi pertanian digital 'Cobain Susu' ini berasal dari kompetitor yang memiliki produk yang sama dengan harga yang lebih rendah. Hal ini tak dapat dipungkiri, mengingat sebagian konsumen memilih produk berdasarkan harga meskipun rasa yang paling utama. Belum tersedianya 'Cobain Susu' dalam bentuk aplikasi khusus membuat inovasi ini rentan ditiru oleh wirausahawan- wirausahawan lainnya (lihat gambar 6). 
Eko Tulus Wibowo -- Pembangunan Ekonomi Pertanian Digital Dalam Mendukung Ketahanan Pangan (Studi di Kabupaten Sleman: Dinas Pertanian, Pangan, dan Perikanan, Daerah Istimewa Yogyakarta)

Gambar 6

Tampilan Logo 'Cobain Susu'

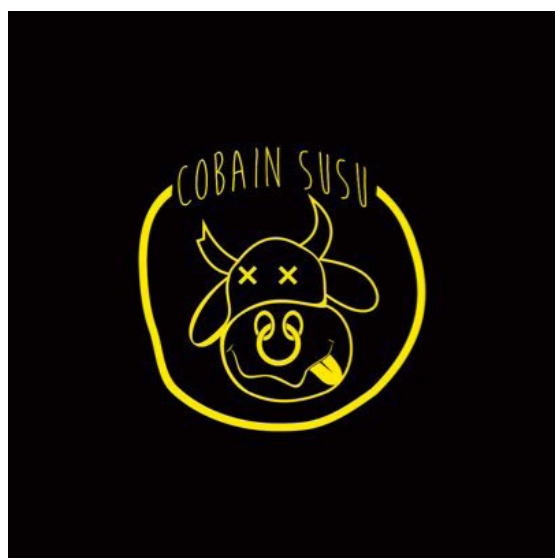

Sumber: Olahan peneliti, 2020

\section{Ketahanan Pangan}

Ketahanan pangan bersifat multidimensi, sehingga penilaian terhadap situasi ketahanan pangan membutuhkan ukuran yang komprehensif dengan melibatkan serangkaian indikator. Pada level nasional, Badan Pusat Statistik (BPS) telah menyusun Indeks Ketahanan Pangan berdasarkan tiga aspek yaitu ketersediaan, akses, dan konsumi pangan. Indikator-indikator tersebut digabungkan untuk menghasilkan nilai komposit ketahanan pangan, yang selanjutnya dijadikan sebagai Indeks Ketahanan Pangan, (Kementan, 2018).

Sektor pertanian yang memiliki hasil berupa pangan termasuk kajian geopolitik dunia. Indonesia menjadi negara yang memilii potensi pada bidang pangan yang tinggi. Konsep ketahanan nasional di Indonesia sejalan dengan konsep ketahanan pangan dari Organisasi Pangan dan Pertanian Dunia (Food and Agriculture Organization/ FAO) yang mengandung arti kondisi dimana semua orang, pada waktu apapun, memiliki akses fisik dan ekonomi terhadap makanan yang cukup, aman dan bergizi yang dapat memenuhi kebutuhan gizi dan preferensi makanan mereka agar dapat hidup secara aktif dan sehat (FAO, 1996). Konsep ini membolehkan adanya suatu tatanan yang mengatur sistem pertanian di suatu negara selama masyarakat memiliki akses secara fisik dan ekonomi terhadap makanan (Ningrum, dkk,. 2017).

Pengembangan ekosistem teknologi pada era 4.0 dinilai sangat penting dalam mengembangkan ekonomi pertanian digital. Hal ini akan berbanding lurus dengan ekonomi pertanian digital yang berkembang aktif sebagai dasar untuk pengembangan lebih lanjut ekonomi nasional. Artinya, meningkatnya ekonomi nasional akan sejalan dengan meningkatnya ketahanan pangan. Teknologi semakin berkembang dan bertambah luas, peran vital sektor pertanian dalam menghasilkan pangan masih belum tergantikan oleh sektor lain. Selain itu, pertumbuhan jumlah penduduk di Indonesia yang terus meningkat harus diimbangi dengan peningkatan produktivitas hasil pertanian. Dari hasil analisis peneliti, dapat dirangkum menjadi tiga aspek dalam pengembangan ekonomi pertanian digital terhadap ketahanan pangan yaitu aspek ketersediaan pangan, aspek akses pangan, dan aspek konsumsi pangan.

Jika dilihat lebih luas, ketahanan pangan dapat diartikan berupa cukupnya kebutuhan pangan oleh masyarakat. Namun, seiring berkembangnya zaman ketahanan pangan tidak hanya dimaknai dengan kecukupan kebutuhan pangan. Seperti yang disampaikan Armawi (2009) bahwa pangan merupakan kebutuhan pokok manusia yang paling hakiki untuk bertahan hidup dalam rangka eksistensinya. Oleh karena itu, ketersediaan bahan pangan sangat perlu di daerah-daerah permukiman dalam jumlah yang cukup, mempunyai mutu yang layak, dan secara medis aman untuk dikonsumsi. Di samping faktor- 
faktor tersebut secara ekonomis persoalan pangan terkait juga dengan kemampuan daya beli masyarakat sehingga produk pangan harus dapat terjangkau oleh penduduk atau konsumennya. Maka dengan itu peneliti merumuskan kriteria ketahanan pangan yang meliputi aspek ketersediaan pangan, akses pangan, dan konsumsi pangan. Di bawah ini adalah uraian selengkapnya.

Pertama, ketersediaan pangan. Ketersediaan pangan berbanding lurus dengan peningkatan jumlah penduduk di Indonesia. Pencapaian keberhasilan penyediaan pangan di masa mendatang dipengaruhi oleh pertumbuhan penduduk. Hasil proyeksi menunjukkan bahwa jumlah penduduk Indonesia selama dua puluh lima tahun mendatang terus meningkat yaitu dari 238,5 juta pada tahun 2010 menjadi 305,6 juta pada tahun 2035 (BPS, 2013).

Berkembangnya teknologi akan meningkatkan kapasitas produksi. Jika dalam kebutuhan pangan pada suatu negara dapat dilihat secara menyeluruh, maka dapat terlihat daerah yang terpenuhi maupun sebaliknya. Jika dilihat dari segi budidaya, melalui ekonomi pertanian digital dapat dilihat data tentang potensi kebutuhan pangan. Dengan adanya data potensi kebutuhan pangan, maka petani mampu melihat peluang pasar sehingga dapat merencanakan komoditas tanaman pangan yang akan dibudidayakan. Perencanaan waktu untuk memulai budidaya akan mengurangi minimnya hasil produksi pertanian, artinya petani dapat memperkirakan waktu tanam dan waktu panen, agar tidak terjadi kekurangan hasil pangan, hal ini dapat menghindari keadaan dimana panen serentak menyebabkan kebutuhan pangan melimpah, begitu juga sebaliknya. Hasil produksi yang selalu ada setiap waktu dapat menjaga ketersediaan pangan.

Ketersediaan pangan harus terjamin bagi masyarakat hingga tingkat rumah tangga bahkan individu untuk memperoleh pangan secara berlanjut sesuai kebutuhan dan mampu hidup sehat dan beraktivitas. Konsep terpenuhinya ketersediaan pangan bagi setiap individu juga memperhatikan hal-hal berkaitan dengan jumlah dan kualitasnya, sehingga dalam ekonomi pertanian digital dalam aspek ketersediaan memenuhi segi kualitas, keberlanjutan, dan kuantitas. Selain itu, dalam ekonomi pertanian digital dapat merangkum semua database yang bisa disebut sebagai big data berupa hasil analisis terpenuhinya ketersediaan pangan secara menyeluruh. Adapun manfaat Big Data sudah banyak dirasakan oleh pelaku bisnis dalam dunia usaha. Big Data dapat membantu pengusaha untuk mengambil keputusan menjadi lebih tepat dan akurat berdasarkan data yang diperoleh. Selain itu adanya Big Data berfungsi untuk mengetahui tanggapan masyarakat terhadap produk-produk yang dipasarkan melalui analisis sentimen yang dilakukan di media sosial. Big Data juga dapat digunakan sebagai acuan dalam menentukan rencana usaha dengan mengetahui perilaku yang dilakukan oleh pelanggan, lebih meningkatkan citra di mata pelanggan, serta mengetahui tren yang terjadi pada pasar maupun keinginan konsumen dalam mendapatkan produk (Sirait, 2016). Dengan demikian, kemajuan teknologi dapat memberikan informasi berupa pola konsumsi masyarakat secara luas. Hal ini memudahkan produsen untuk menyiapkan produksi produk pangan yang dapat memberikan keuntungan, sehingga dengan digitalisasi akan menjaga tercukupinya ketersediaan kebutuhan pangan masyarakat. 
Eko Tulus Wibowo -- Pembangunan Ekonomi Pertanian Digital Dalam Mendukung Ketahanan Pangan (Studi di Kabupaten Sleman: Dinas Pertanian, Pangan, dan Perikanan, Daerah Istimewa Yogyakarta)

Di Kabupaten Sleman, produksi pangan utama yang berasal dari padi sawah dan padi ladang Kabupaten Sleman pada tahun 2018 tercatat sebanyak 249.878 ton (Gabah kering giling). Sedangkan, jumlah penduduk Sleman tahun 2018 sebesar 1.206.714 jiwa. Jika dianalisis, hasil produksi pangan utama berupa padi sawah dan padi ladang yaitu 200 kg (Gabah kering giling) per jiwa atau setara dengan 125,48 $\mathrm{kg}$ beras per jiwa dalam satu tahun, sedangkan menurut Kementerian Pertanian konsumsi beras per orang sebesar $124 \mathrm{~kg}$ per tahun. Hal ini menunjukkan bahwa ketersediaan pangan utama Kabupaten Sleman terpenuhi. Pada tahun sebelumnya yaitu tahun 2017, jumlah produksi 290.627 ton (Gabah kering giling) dengan jumlah penduduk 1.193.512 maka perhitungan bahan pangan utama sebesar 150, $57 \mathrm{~kg}$ beras per jiwa dalam satu tahun. Hal ini dapat diasumsikan tercukupinya kebutuhan pangan utama pada tahun- tahun selanjutnya mengingat jumlah penduduk Kabupaten Sleman pada tahun 2019 yaitu hanya sebesar 1.075.575 jiwa. Selain itu, ketersediaan kebutuhan pangan makin meningkat dengan adanya inovasi dalam teknologi. Hal ini dapat dilihat dari data produksi cabe yang terus meningkat tiap tahun, mulai dari tahun 2016 sebesar 43.626 kwintal, tahun 2017 sebesar 60.668 kwintal, hingga tahun 2018 sebesar 71.786 kwintal. Hal tersebut menunjukkan bahwa peningkatan produksi harus diimbangi dengan inovasi pemasaran. Pemanfaatan ekonomi pertanian digital dapat memberikan informasi dalam menentukan proses budidaya sehingga tetap menjaga ketersediaan kebutuhan bahan pangan menjadi terpenuhi serta tidak terjadi kekurangan.

Kedua, akses pangan. Kemudahan akses pangan dinilai menekan inflasi harga pangan.
Inflasi harga pangan dapat mempengaruhi stabilitas ekonomi negara. Sektor pangan dapat di pengaruhi oleh faktor politik serta kebijakan tentang pangan yang menyebabkan inflasi harga pangan sehingga keterkaitan kebijakan pangan dapat dilihat dari segi kestabilan harga pangan agar tidak terjadi inflasi harga pangan. Stabilitas harga pangan yang dapat tercapai melalui ekonomi pertanian digital. Ekonomi pertanian digital membuat akses terhadap pangan dapat terjadi secara langsung sesuai kebijakan pangan sehingga menyebabkan harga pangan menjadi stabil serta mengurangi ketidakpastian petani dan menjamin harga pangan bagi konsumen. Dari observasi peneliti, permasalahan yang sering muncul pada petani berupa peran makelar/ pedagang pengumpul atau produsen sekunder yang menguasai permodalan dan rantai pasok/ tata-niaga pertanian, sehingga petani sebagai produsen utama (primer) hanya memperoleh keuntungan dari kegiatan usaha tani lebih sedikit bahkan mengalami kerugian. Di sisi lain, produsen sekunder dapat mengambil keuntungan yang berlipat ganda.

Ekonomi pertanian digital memudahkan akses terhadap produk pertanian. Hal ini dinilai meningkatkan efisiensi (efficiency) konsumen dalam mendapatkan produk pertanian. Jain dan Kumar (2011) mengemukakan tentang efficiency. Efficiency dapat diartikan sebagai dimensi dari kualitas pelayanan elektronik yang berupa kemampuan pelanggan untuk mendapatkan akses terhadap website, kemampuan pelanggan untuk mencari produk maupun informasi yang berkaitan dengan produk tersebut, serta meninggalkan situs bersangkutan dengan upaya minimal. Efficiency dan kepuasan pelanggan memiliki hubungan yang erat yaitu efficiency merupakan salah satu dimensi dari kualitas pelayanan 
elektronik yang berdampak pada kepuasan pelanggan.

Akses pangan (food accessibility) adalah kemampuan rumah tangga untuk memperoleh cukup pangan, baik yang berasal dari produksi sendiri, pembelian, barter, hadiah, pinjaman, dan bantuan pangan maupun kombinasi di antara kelimanya. Ketersediaan pangan di suatu daerah yang sudah tercukupi belum tentu sejalan dengan adanya akses yang memadai baik secara kuantitas maupun keragaman pangan oleh semua rumah tangga pada daerah tersebut (Rachmaningsih dan Priyarsono, 2012). Ekonomi pertanian digital memberikan kemudahan dalam akses pangan melalui pembelian.

Jika dikaji secara teknis, dukungan transportasi Kabupaten Sleman sudah memadai secara infrastruktur dan transportasi sehingga penggunaan ekonomi pertanian digital akan lebih memberikan dampak efisien dengan dukungan infrastrukur dan transportasi. Panjang jalan kabupaten tahun 2018 adalah $699,50 \mathrm{~km}$ dengan $377,50 \mathrm{~km}$ dalam kondisi baik dan jalan dengan jenis permukaan jalan berupa aspal sepanjang 688,87 km. Selain itu data kendaraan juga menunjukkan jumlah yang banyak yaitu sebanyak 1.085 mobil barang pick-up, 516 truk, dan 40.317 sepeda motor yang menunjang sarana prasarana dalam distribusi logistik berupa produk pertanian (BPS Kabupaten Sleman, 2019).

Kelancaran distribusi produk dalam perspektif ekonomi pertanian digital dapat direalisasikan dengan jangkauan akses antar kecamatan dalam kabupaten. Artinya, dengan adanya dukungan infrastrukur dan transportasi yang memadai perlu adanya pemahaman secara teknis proses ekonomi pertanian digital. Adanya ekonomi pertanian digital memberikan kemudahan dalam mengetahui ketersediaan produk pertanian dan memudahkan konsumen maupun masyarakat untuk mengakses produk pertanian sesuai kebutuhan yang ada, sehingga integrasi yang baik antar kecamatan dalam kabupaten mendukung ketahanan pangan Kabupaten Sleman.

Ketiga, konsumsi pangan. Kebutuhan pangan dari segi konsumsi dilihat dari sejauh mana masyarakat mengkonsumsi pangan yang beraneka ragam. Indonesia masih identik dengan pola konsumsi pangan berupa nasi. Hal ini yang membuat bahan pangan lain yang memiliki kandungan gizi sama bahkan melebihi kandungan gizi beras jarang untuk dimanfaatkan menjadi makanan pokok. Pemerintah telah menerbitkan Peraturan Presiden (Perpres) No. 22 Tahun 2009 Tentang Kebijakan Percepatan Penganekaragaman Konsumsi Pangan Berbasis Sumberdaya Lokal. Perpres ini mengamanatkan bahwa untuk mewujudkan penganekaragaman pangan diperlukan berbagai upaya secara sistematis dan terintegrasi. Konsumsi pangan secara Beragam Bergizi Seimbang (B2SA) ini bertujuan untuk meningkatkan kesadaran masyarakat dalam membudayakan pola konsumsi pangan beragam, bergizi, seimbang, dan aman untuk hidup sehat, aktif, dan produktif (Badan Ketahanan Pangan, 2020). Soekirman (1996) juga menjelaskan bahwa kenaikan harga pangan bagi keluarga yang tidak bekerja atau yang bekerja tetapi penghasilannya tidak cukup, dapat mengancam kebutuhan gizinya yang berarti ketahanan pangan keluarganya terancam. Sejalan dengan teori Big Data pada aspek sebelumnya, adanya ekonomi pertanian digital akan menghasilkan data pola konsumsi sehingga dapat melihat jenis makanan apa yang sering dikonsumsi. Analisis dapat disimpulkan dengan melihat pola konsumsi dengan pemenuhan kebutuhan makanan. 
Eko Tulus Wibowo -- Pembangunan Ekonomi Pertanian Digital Dalam Mendukung Ketahanan Pangan (Studi di Kabupaten Sleman: Dinas Pertanian, Pangan, dan Perikanan, Daerah Istimewa Yogyakarta)

Dalam meningkatkan kebutuhan makanan maka diperlukan pola penganekaragaman jenis makanan yang dikonsumsi dengan pola Beragam Bergizi Seimbang dan Aman (B2SA). Jika di lihat dari sisi kesehatan, hal ini dinilai sangat berpengaruh dengan terpenuhinya asupan pada makanan yang dikonsumsi maka akan sejalan dengan meningkatnya kesehatan tubuh.

Di Kabupaten Sleman sendiri data skor pola pangan harapan (PPH) digabungkan dengan skor PPH tingkat Provinsi Daerah Istimewa Yogyakarta tahun 2017 adalah 89,03 . Tahun 2018 adalah 89,92 serta data sementara tahun 2019 adalah 95,50. Jika dilihat dari capaian pangan harapan, skor PPH mendekati angka 100 artinya pola konsumsi pangan di Kabupaten Sleman dinilai bagus. Jika dijabarkan Pola Konsumsi Padi- padian (Skor PPH Standar 25) tahun 2017 hingga tahun 2019 memiliki skor yang sama yaitu 25. Sedangkan, Pola Konsumsi Sayur dan Buah (Skor PPH Standar 30) mengalami peningkatan dari tahun 2017 sebesar 23,20 kemudian tahun 2018 sebesar 23,81 dan tahun 2019 sebesar 30, (BPS Kabupaten Sleman, 2020). Hal tersebut menunjukkan bahwa pemanfaatan ekonomi pertanian digital dapat mendukung ketahanan pangan pada aspek konsumsi. Dengan dukungan pola pangan yang beragam maka skor PPH pada masingmasing jenis komoditas pangan memenuhi angka standar PPH.

Penggunaan ekonomi pertanian digital dalam beberapa hal cukup membantu kelangsungan proses produksi dari hulu hingga proses hilir berupa pemasaran produk pertanian. Namun, beberapa hal pada aspek ketahanan pangan masih dinilai kurang efektif. Keuntungan ekonomi pertanian digital dalam mendukung ketahanan pangan dapat dilihat dari manfaat yang diterima pengguna. Pada aspek produksi dan distribusi menunjukkan pemanfaatan ekonomi pertanian digital cukup efektif. Tak dapat dipungkiri, bahwa aspek distribusi/ akses memegang peranan paling penting dalam aspek ketahanan pangan, karena dalam persaingan global dengan era kemajuan teknologi seperti saat ini membutuhkan hal yang serba cepat. Kendati demikian, dalam hal pemanfaatan ekonomi pertanian digital masih menemui kekurangan berupa kurang efektifnya media sosial ataupun aplikasi yang digunakan. Jika melihat dari pemanfaatan ekonomi pertanian digital berdasarkan aspek ketahanan pangan, aspek konsumsi menjadi aspek yang memiliki persentase terbesar dalam hal penggunaan platform yang kurang efektif. Hal ini karena pengguna media digital masih belum sadar akan pentingnya mengatur pola konsumsi produk pertanian. Aspek konsumsi mencakup kebutuhan pangan yang kaitannya dengan kandungan gizi yang mendukung kesehatan manusia. Sementara, masyarakat masih enggan memperhatikan konsumsi pangan yang berkaitan dengan pangan yang beragam, bergizi seimbang, dan aman (B2SA). Berdasarkan uraian di atas, problem utama beserta solusi terkait ekonomi pertanian digital dalam mendukung ketahanan pangan yang disajikan pada tabel 7 .

Konsepsi ketahanan merupakan rumusan dari pemahaman berupa kemampuan bertahan dalam menghadapi suatu keadaan. Ketahanan merupakan kondisi yang menjadi acuan keberhasilan agar tidak terjun pada kehancuran. Suatu negara pada umumnya memiliki persepsi terhadap konsep ketahanan sesuai dengan kepentingan negara tersebut. Indonesia memiliki jumlah penduduk terbesar ke empat di dunia dan salah satu kepentingan nasional negaranya adalah pangan. Oleh 
Tabel 7

Problem Utama Dan Solusi Terkait Tetahanan Pangan

\begin{tabular}{|c|c|c|}
\hline $\begin{array}{c}\text { Aspek ketahanan } \\
\text { pangan }\end{array}$ & Problem utama ekonomi pertanian digital & Solusi/ strategi \\
\hline $\begin{array}{l}\text { Produksi/ } \\
\text { ketersediaan }\end{array}$ & $\begin{array}{l}\text { - Ketersediaan informasi tentang produk } \\
\text { pertanian dan kualitasnya yang terbatas } \\
\text { - Sarana produksi yang masih kurang } \\
\text { - Kurang tepatnya perhitungan budidaya dan } \\
\text { waktu panen }\end{array}$ & $\begin{array}{l}\text { - } \text { Bermitra dengan Dinas, Kementerian } \\
\text { Pertanian, dan peran pemuda tani } \\
\text { - Menjalin kemitraan dengan Dinas, } \\
\text { Kementerian, maupun perusahaan swasta } \\
\text { - Pengembangan Sumber Daya Manusia }\end{array}$ \\
\hline Distribusi/ akses & $\begin{array}{l}\text { - Kecepatan respon terhadap produk } \\
\text { pertanian yang lambat } \\
\text { - Kendala sarana prasarana berupa jaringan } \\
\text { - Aplikasi/website yang belum mampu } \\
\text { diakses }\end{array}$ & $\begin{array}{l}\text { - Penguatan Sumber Daya Manusia } \\
\text { - } \quad \text { Penjalin kemitraan dengan Kemkominfo } \\
\text { - Pemuda tani serta peran developer }\end{array}$ \\
\hline Konsumsi & $\begin{array}{l}\text { - Masyarakat yang kurang peduli terhadap } \\
\text { gizi pangan } \\
\text { - Minimnya aplikasi tentang kandungan gizi } \\
\text { produk pertanian }\end{array}$ & $\begin{array}{l}\text { - Pengembangan Sumber Daya Manusia } \\
\text { - Menjalin kemitraan dengan developer, } \\
\text { perusahaan swasta, Dinas Pertanian, } \\
\text { hingga Kementerian Kesehatan. }\end{array}$ \\
\hline
\end{tabular}

Sumber: Olahan peneliti, 2020

karena itu, kondisi pangan yang memiliki sifat tahan terhadap suatu keadaan akan berpengaruh terhadap kemampuan Indonesia dalam menjaga ketahanan nasionalnya.

Ketahanan pangan termasuk ke dalam kajian ketahanan nasional model mikro yang perlu diperhatikan untuk menjaga stabilitas baik di tingkat nasional maupun sub-nasional. Oleh karena itu, muncul konsepsi ekonomi pertanian digital yang diadopsi dari konsepsi ekonomi pertanian pada segi off farm bidang pertanian. Konsep ini pada dasarnya sama, menyediakan jasa perantara penjualan produk hasil pertanian yang memiliki kelebihan secara cepat, tidak memerlukan waktu yang lama, serta saling terhubung tanpa hambatan jarak. Ekonomi pertanian digital yang dapat menjadi kiblat baru dalam langkah lanjutan pascapanen hasil pertanian harus dilihat dari beragam sudut pandang. Kemajuan teknologi menyebabkan kekuatan mengarah pada segelintir pihak/ perorangan yang dapat berdampak pada penghancuran ekologis dikarenakan sistem ekonomi global yang dipisahkan dari tempat semestinya, sehingga menyebabkan globalisasi ekonomi terlihat dengan harga yang tinggi. Maka dari itu, keinginan menciptakan ketahanan pangan dengan adanya teknologi dinilai relevan terhadap perkembangan zaman, namun perlu dicermati pula dampak secara eksplisit yang tidak mampu dilihat oleh masyarakat.

Ke depannya, kemajuan teknologi perlu diperhatikan dengan seksama. Pembangunan yang semula didasarkan pada kepentingan nasional semakin tergerus dan mengarah pada kepentingan golongan/ perusahaan bahkan kepentingan perseorangan semata untuk mencari keuntungan. Maka perlu dipahami secara mendalam, bahwa kepentingan terkait kemajuan teknologi sudah benar- benar mampu memberikan keuntungan secara merata atau belum. Munculnya rasa tidak percaya bagi sebagian masyarakat berkorelasi pada kejanggalan transparansi pembagian hasil keuntungan dan kepentingan segelintir pihak. Pada saat yang bersamaan, petani yang masih menjaga kearifan lokal dalam bercocok tanam perlu menjadi prioritas utama dalam era kemajuan teknologi. 
Eko Tulus Wibowo -- Pembangunan Ekonomi Pertanian Digital Dalam Mendukung Ketahanan Pangan (Studi di Kabupaten Sleman: Dinas Pertanian, Pangan, dan Perikanan, Daerah Istimewa Yogyakarta)

Pada akhirnya, implikasi ketahanan pangan ini memiliki keterkaitan terhadap konsepsi ketahanan nasional yang mengarah pada ketahanan pangan dengan tidak meninggalkan nilai- nilai yang terkandung dalam kehidupan berbangsa dan bernegara. Pembangunan ekonomi pertanian digital dengan konsep yang telah dijelaskan di atas perlu dilakukan, dengan tidak meninggalkan pemahaman yang mengutamakan kepentingan masyarakat, terutama berpihak kepada petani sebagai subyek utama yang menjadi sumber produksi utama pangan melalui pertanian.

\section{SIMPULAN}

Berdasar penjelasan tersebut di atas dapat ditarik simpulan sebagai berikut.

Pertama, pembangunan ekonomi pertanian digital dapat berupa aplikasi maupun website, dengan dukungan pemberian pemahaman kepada masyarakat, hingga menjelaskan potensi hasil produk pertanian yang erat kaitannya dengan manfaat ekonomi pertanian digital. Ekonomi pertanian digital selain meningkatkan penghasilan juga dapat mendorong petani memenangkan persaingan secara global. Hal ini menjawab tantangan ekonomi pertanian digital yang memiliki konsep yang diadopsi dari ekonomi pertanian dikombinasikan dengan kemajuan teknologi. Ekonomi pertanian digital juga dipandang sebagai ilmu baru yang dalam pemanfaatannya sebagai pembelajaran dalam mengikuti pesatnya perkembangan teknologi informasi dan komunikasi.

Kedua, pembangunan ekonomi pertanian digital dapat mendukung ketahanan pangan dilihat dari peningkatan manfaat yang diterima pengguna pada masing- masing aspek ketahanan pangan. Namun, kemajuan teknologi perlu diperhatikan dengan seksama.
Pembangunan ekonomi pertanian digital yang mendukung ketahanan pangan perlu dilakukan dengan tidak meninggalkan pemahaman yang mengutamakan kepentingan masyarakat, terutama keuntungan berpihak kepada petani sebagai sumber produksi utama pangan melalui pertanian.

Selanjutnya, direkomendasikan hal sebagai berikut.

Pertama, penelitian lebih lanjut masih sangat diperlukan untuk semakin mendukung pembangunan ekonomi pertanian digital sehingga dalam pengembangannya dapat dibangun relasi dengan perusahaan maupun instansi negeri/ swasta.

\section{DAFTAR PUSTAKA}

Afifah, Aisyah Nur, 2018, Penerapan Digital Marketing Dan Pengaruhnya Terhadap Keberhasilan Usaha Mikro, Kecil Dan Menengah Sektor Kreatif Di Indonesia Dan Malaysia. Tesis, Bogor, Institut Pertanian Bogor

Akkerman, R., P. Farahani, dan M. Grunow, 2010, Quality, safety and sustainability in food distribution: a review of quantitative operations management approaches and challenges. Or Spectrum, Vol. 32, No. 4, hh. 863-904.

Armawi, A., 2009, Memaknai Kembali Ketahanan Pangan. Jurnal Ketahanan Nasional, Vol. 14, No. 1, hh.77-87.

Badan Ketahanan Pangan, 2020, Gerakan Konsumsi Pangan Beragam Bergizi Seimbang dan Aman (B2SA). <http:// bkp.pertanian.go.id/gerakan-konsumsipangan-beragam-bergizi-seimbang-danaman-b2sa pada 20 Januari 2020 pukul 22.30 WIB>.

Badan Pertanahan Kabupaten Sleman, 2019, Luas Lahan menurut Penggunaannya 
di Kabupaten Sleman Tahun 20152018. <https://slemankab.bps.go.id/ statictable/2019/07/08/483/luas-lahanmenurut-penggunaannya-di-kabupatensleman-2015-2018-ha-.html> pada 15 Mei 2020 pukul 19.40 WIB $>$

Badan Pusat Statistik, 2013, Proyeksi Penduduk Indonesia Indonesia Population Projection 2010-2035. <https://www. bps.go.id/publication/2013/10/07/05 $3 \mathrm{~d} 25$ bed2e4d62aab3346ec/proyeksipenduduk-indonesia-2010-2035>.html pada 19 Januari 2020 pukul 17.10 WIB.

Bahua, 2016, Mampukah Petani Kita Bersaing di Tengah Pasar Global. Tabloid Insprirasi Membawa Pencerahan Bangsa. Vol. I, No. 3.

Beske, P., A.Land, dan S. Seuring, 2014, Sustainable supply chain management practices and dynamic capabilities in the food industry: A critical analysis of the literature. International Journal of Production Economics, 152: hh.131-143

BPS Kabupaten Sleman, 2019, Kabupaten Sleman Dalam Angka 2019, Yogyakarta: CV. Magna Raharja Tama (MAHATA)

BPS Kabupaten Sleman, 2020, Kabupaten Sleman Dalam Angka 2020

Buraeva, E., 2014, Innovation in Agricultural as a factor in the growth of efficiency of Agricultural Production. ScientificMethodical Electrnic Journal "Concept", hh. 2161-2165

Durou, E, J.A.Jaoude, dan R. Khalife, 2016, The Changing Role of People Management in the Digital Age. Deloitte \& Touche (ME), hh.1-7.

FAO, 1996, World food summit: Rome declaration on world food security and World Food summit plan of action. FAO.
Fatchiya, A. dan S. Amanah, 2016, Penerapan inovasi teknologi pertanian dan hubungannya dengan ketahanan pangan rumah tangga petani, Jurnal Penyuluhan, Vol.12, No. 2, hh.190-197. Jain, P., dan N. Kumar, 2011, Measurement of e-service quality: An empirical study on online railway ticket reservation website service. Sri Krishna International Research \& Educational Consortium, Vol. 2. No. 1.

Jaya, 2018, Nasib Petani Dan Ketahanan Pangan Wilayah (Studi Tentang Kebijakan Pemerintah Dan Respons Masyarakat Desa Mulyodadi, Bantul Ketika Harga Komoditas Pertanian Naik). Jurnal Ketahanan Nasional, Vol. 24, No. 1, hh.77-93.

Kemenkominfo, 2019, Menkominfo Jelaskan Beda Ekonomi Digital dan Revolusi Industri. <https://www.kominfo. go.id/content/detail/17249/banyaksalah-kaprah-menkominfo-jelaskanbeda-ekonomi-digital-dan-revolusiindustri/0/berita_satker> pada $12 \mathrm{Mei}$ 2019 pukul 21.15 WIB.

Kementan, 2015, Rencana Strategis Kementerian Pertanian Tahun 2015 2019.

Kementan, 2018, Indeks Ketahanan Pangan Indonesia 2018, Badan Ketahanan Pangan Kementerian Pertanian

Kuznetsova, I., O.Voronkova, S. Bakhvalov, I. Ruiga, dan G. Zhuruli, 2018, Formation of Human Capital as a Key Factor in Ensuring the National Security of Agriculture in the Digital Economy. European Research Studies, Anixis Vol. 21, No. 3, hh. 73-83.

Lubis, D., 2010, Pemanfaatan teknologi informasi dan komunikasi mendukung 
Eko Tulus Wibowo -- Pembangunan Ekonomi Pertanian Digital Dalam Mendukung Ketahanan Pangan (Studi di Kabupaten Sleman: Dinas Pertanian, Pangan, dan Perikanan, Daerah Istimewa Yogyakarta)

pembangunan pertanian berkelanjutan, Prosiding seminar IPB.

Mc Kinsey Global Institute, 2019, Digital India: Technology to transform a connected nation.

Moleong, Lexy J., 2011, Metodologi Penelitian Kualitatif. Bandung: Remaja Rosda Karya

Nedelkin, A.A., V.A.Titov, E.I. Tikhomirova, Y.D. Romanova, 2016, The processing's automation of digital documents for hypertext scientific library. $A R P N$ Journal of Engineering and Applied Sciences, Vol.11, No. 7, hh. 4681-4684. Ningrum ,V., A.Wiratri, D. Harfina, G.B. Aji, dan P. Prasetyoputra, 2017, Pemuda dan Pertanian Berkelanjutan: Dependensi, Strategi, dan Otonomi. Jakarta: Pustaka Sinar Harapan

Nurhadi, Sandi, 2010, Strategi Pengembangan Ketahanan Pangan (Studi di Kabupaten Bantul Propinsi DIY), Yogyakarta: Universitas Gadjah Mada.

Peraturan Presiden No. 22 Tahun 2009 Tentang Kebijakan Percepatan Penganekaragaman Konsumsi Pangan Berbasis Sumberdaya Lokal.

Peraturan Menteri Pertanian Republik Indonesia Nomor 41/Permentan/ OT.140/3/2014 Tentang Pedoman Perencanaan Pembangunan Pertanian Berbasis e-Planning

Rachmaningsih, T. and Priyarsono, D.S., 2012. Ketahanan pangan di kawasan timur Indonesia. Jurnal Ekonomi dan Pembangunan Indonesia, Vol. 13, No. 1, hh.1-18.
Rahim, A., S. Supardi, dan D. Hastuti, 2012, Model Analisis Ekonomi Pertanian, Makassar: Badan Penerbit Universitas Negeri Makassar Makassar

Sirait, E.R.E., 2016, Implementasi Teknologi Big Data Di Lembaga Pemerintahan Indonesia. Jurnal Penelitian Pos dan Informatika, Vol. 6, No. 2, hh.113-136. Soekirman, 1996, Ketahanan Pangan : Konsep, Kebijaksanaan dan Pelaksanaannya. Makalah, disampaikan pada Lokakarya Ketahanan pangan Rumah Tangga, Yogyakarta, 26-30 Mei 1996.

Subejo, 2007, Memahami dan Mengkritisi Kebijakan Pembangunan Pertanian di Indonesia. Makalah Ilmiah Pada Temu Naional Mahasiswa Pertanian Indonesia/Latihan Kepemimpinan Dan Manajemen Mahasiswa (LKMM), Dewan Mahasiswa Fakultas Pertanian UGM, Yogyakarta 15 Februari 2007.

Subejo, 2018, Akses, Penggunaan Dan Faktor Penentu Pemanfaatan Teknologi Informasi Dan Komunikasi Pada Kawasan Pertanian Komersial Untuk Mendukung Ketahanan Pangan Di Perdesaan Yogyakarta. Jurnal Ketahanan Nasional, Vol 24, No. 1.

Undang-Undang Republik Indonesia Nomor 18 Tahun 2012 Tentang Pangan.

Warr, P., 2011, Food Security vs. Food SelfSufficiency: The Indonesian Case. The Arndt-Corden Department of Economics Crawford School of Economics and Government ANU College of Asia and the Pacific 